\title{
Alcohol Regulates BK Surface Expression via Wnt/ $\beta$-Catenin Signaling
}

\author{
[C. Cristina Velázquez-Marrero, ${ }^{1}$ Alexandra Burgos, ${ }^{1,4}$ - José 0. García, ${ }^{1,3}$ @Stephanie Palacio, ${ }^{1}$ @Héctor G. Marrero, ${ }^{1}$ \\ (1)Alexandra Bernardo, ${ }^{1}$ Juliana Pérez-Laspiur, ${ }^{2}$ Marla Rivera-Oliver, ${ }^{1,4}$ CGarrett Seale, ${ }^{1}$ and Steven N. Treistman ${ }^{1}$ \\ ${ }^{1}$ Institute of Neurobiology, University of Puerto Rico Medical Sciences Campus, San Juan, Puerto Rico 00901, ${ }^{2}$ RCMI Translational Proteomics Center \\ University of Puerto Rico Medical Sciences Campus, San Juan, Puerto Rico 00936, 3University of Puerto Rico Natural Sciences Department, Carolina \\ Campus, San Juan, Puerto Rico 00984, and ${ }^{4}$ University of Puerto Rico Río Piedras Campus, San Juan, Puerto Rico 00931
}

It has been suggested that drug tolerance represents a form of learning and memory, but this has not been experimentally established at the molecular level. We show that a component of alcohol molecular tolerance (channel internalization) from rat hippocampal neurons requires protein synthesis, in common with other forms of learning and memory. We identify $\beta$-catenin as a primary necessary protein. Alcohol increases $\beta$-catenin, and blocking accumulation of $\beta$-catenin blocks alcohol-induced internalization in these neurons. In transfected HEK293 cells, suppression of Wnt/ $\beta$-catenin signaling blocks ethanol-induced internalization. Conversely, activation of Wnt $/ \beta$ catenin reduces BK current density. A point mutation in a putative glycogen synthase kinase phosophorylation site within the $S 10$ region of $\mathrm{BK}$ blocks internalization, suggesting that $\mathrm{Wnt} / \beta$-catenin directly regulates alcohol-induced $\mathrm{BK}$ internalization via glycogen synthase kinase phosphorylation. These findings establish de novo protein synthesis and $\mathrm{Wnt} / \beta$-catenin signaling as critical in mediating a persistent form of BK molecular alcohol tolerance establishing a commonality with other forms of long-term plasticity.

Key words: beta-catenin; BK; downregulation; EtOH; tolerance; Wnt

Significance Statement

Alcohol tolerance is a key step toward escalating alcohol consumption and subsequent dependence. Our research aims to make significant contributions toward novel, therapeutic approaches to prevent and treat alcohol misuse by understanding the molecular mechanisms of alcohol tolerance. In our current study, we identify the role of a key regulatory pathway in alcohol-induced persistent molecular changes within the hippocampus. The canonical Wnt/ $\beta$-catenin pathway regulates BK channel surface expression in a protein synthesis-dependent manner reminiscent of other forms of long-term hippocampal neuronal adaptations. This unique insight opens the possibility of using clinically tested drugs, targeting the $\mathrm{Wnt} / \beta$-catenin pathway, for the novel use of preventing and treating alcohol dependency.

\section{Introduction}

Alcohol tolerance has long been studied as a predictor of future alcoholism (Treistman and Wilson, 1991; Schuckit, 1994). Behavioral acute tolerance, defined as the decrease in effect of a drug

\footnotetext{
Received Feb. 11, 2016; revised June 22, 2016; accepted July 27, 2016

Author contributions: C.V.-M. and S.N.T. designed research; C.V.-M., A. Burgos, J.0.G., S.P., H.G.M., A. Bernardo, J.P.-L., and G.S. performed research; C.V.-M., A. Burgos, J.O.G., S.P., H.G.M., and M.R.-0. analyzed data; C.V.-M. and S.N.T. wrote the paper.

This work was supported by the National Institute on Alcohol Abuse and Alcoholism Grant 1R01 AA017920 and 1R01 AA017920 to S.N.T., 5P20GM103642 COBRE Project Grant to C.V.-M., MBRS-RISE Fellowship awarded to S.P., Imaging Core at the Institute of Neurobiology National Science Foundation Grant DBI-0115825, Department of Defense Grant 52680-LS-IS, and National Institute of Minority Health and Health Disparities Grant G12MD 007600, which provided research infrastructure support. We thank Guillermo Yudowski, Joshua J. Rosenthal, Manuel E. Díaz, Bruno Marie, Jorge Miranda, Mark Miller, Loyda M. Melendez, Jacqueline Flores-Otero, Jessica M. Soto, and members of the C.V.-M. and S.N.T. laboratory for stimulating discussions and valuable comments; Carlos Nogueras-Ortiz for help with troubleshooting experiments; and Dhasakumar S. Navaratnam (Yale University) for tThe hSloAA stably transfected HEK293 cells.

The authors declare no competing financial interests.
}

within a brief exposure time despite unaltered concentration, is a primary precursor for increased intake leading to dependency and abuse. Behavioral tolerance has its roots in adaptations to ethanol (EtOH) at the cellular and molecular levels, termed "molecular tolerance” (Treistman and Wilson, 1991; Feinberg-Zadek et al., 2008; Pietrzykowski et al., 2013; Velázquez-Marrero et al., 2014). Drug tolerance shares many features with memory acquisition and consolidation noted in the literature. For example, just as the persistence of a memory is a function of the stimulus protocol used (Hawkins et al., 1983; Siegelbaum and Bolshakov, 1996; Siegelbaum and Kandel, 1991); the persistence of molecu-

Correspondence should be addressed to either Dr. Steven N. Treistman or Dr. Cristina Velázquez-Marrero, Institute of Neurobiology, University of Puerto Rico Medical Sciences Campus, 201 Blvd del Valle, San Juan, Puerto Rico 00901. E-mail:Steven.Treistman@upr.edu or Cristina.Velazquez1@upr.edu.

DOI:10.1523/JNEUROSCI.0491-16.2016

Copyright $\odot 2016$ the authors $\quad 0270-6474 / 16 / 3610625-15 \$ 15.00 / 0$ 
lar tolerance is a function of the temporal pattern of drug exposure, with a markedly nonlinear relationship (VelázquezMarrero et al., 2011). Indeed, a number of authors have proposed that drugs of abuse, such as alcohol, may "hijack" neural pathways that underlie learning and memory (Kauer and Malenka, 2007; Mameli et al., 2009; Pascoli et al., 2014). Similarly, the importance of protein synthesis has been observed for both longterm memory formation (Bliss and Collingridge, 1993; Frey and Morris, 1997; Casadio et al., 1999) and the development of tolerance to EtOH-induced motor impairment in rats (Bitrán and Kalant, 1993).

Our current study focuses on the role of protein synthesis in the development of a persistent form of BK channel molecular tolerance (i.e., internalization) (Pietrzykowski et al., 2004; Mulholland et al., 2009). We show that EtOH-induced redistribution of BK channels, away from the cell surface, is under translational control in both hippocampus primary neurons and human embryonic kidney (HEK) 293 cells. Identification of the proteins implicated in the process led us to the Wnt signaling system; in particular, $\beta$-catenin (Bian et al., 2011) directly interacts and regulates hSlo $\alpha$ surface expression. The link between $\beta$-catenin and BK channel molecular tolerance is particularly interesting in light of recent evidence that $\beta$-catenin plays an important role in the development of LTP (Chen et al., 2006; Oliva et al., 2013), thought to represent a molecular readout of learning and memory (Casadio et al., 1999; Lee and Silva, 2009). Most recently, it has also been shown to be critical in regulating behavioral resilience in mouse models of neuropsychiatric disorders, such as depression (Dias et al., 2014). Dias et al. (2014) showed that $\beta$-catenin mediates proresilient and anxiolytic effects in the nucleus accumbens, the same brain-specific regulatory network involved in the reward pathway targeted by alcohol.

Extensive recent evidence in the literature highlights the importance of the BK channel molecule in both intoxication and alcohol tolerance (Cowmeadow et al., 2006; Brodie et al., 2007; Levitan, 2008; Martin et al., 2008; Mulholland et al., 2009; Treistman and Martin, 2009; Ghezzi et al., 2010; Bettinger and Davies, 2014; Dopico et al., 2014). The influence of EtOH on BK channel function has been evident across species (Bettinger and Davies, 2014), underlining its importance in the development of alcohol tolerance and subsequent increased consumption. Therefore, understanding the regulatory mechanism of BK channel surface expression triggered during rapid $\mathrm{EtOH}$ exposure can provide important insights into possible therapeutic targets impacting drinking behavior.

\section{Materials and Methods}

\section{HEK293 cell culture}

The cells used in these studies included stably transfected HEK293 cells and primary culture hippocampal neurons from E18 rats. The HEK293 cells were stably transfected with $\mathrm{BK} \alpha$ subunit Zero (or Insertless). The BK channel is composed of the pore-forming $\alpha$-subunit, which has several splice isoforms deriving from the same gene, Slo. The ZERO (or Insertless) isoform has been well characterized for its sensitivity to EtOH within the physiological concentration range $(25 \mathrm{~mm}$, which approximates the legal intoxication level) (Pietrzykowski et al., 2008). The cells were cultured in DMEM, 10\% FBS, 2.5 mM HEPES, 1\%; Pen/Strep, 1 mM $\mathrm{Na}^{+}$pyruvate and $2 \mathrm{~mm}$ GlutaMax (Sigma-Aldrich). For the experiments, the cells were plated on either $35 \mathrm{~mm}$ Petri dishes (Falcon) or high tolerance \#1.50.170 mm glass-bottom dishes (MatTek) for electrophysiology and were left to grow from 24 to $72 \mathrm{~h}$ before incubation began. Experiments prepared for confocal microscopy required that cells be plated on glass coverslips placed within the $35 \mathrm{~mm}$ Petri dish during treatment and incubation.

\section{Primary neuronal culture}

Hippocampal neuron cultures were prepared using embryonic Sprague Dawley rat hippocampal tissue (E18) of either sex that was shipped overnight in Hibernate E media (BrainBits). They were identified by their pyramidal shape, which contrasts significantly from glial cells. Briefly, hippocampi were transferred to HBSS containing $10 \mathrm{~mm}$ HEPES and incubated for $15 \mathrm{~min}$ at $37^{\circ} \mathrm{C}$ with $0.25 \%$ trypsin. Hippocampi were then triturated in DMEM containing 10\% FBS, $0.5 \mathrm{~mm}$ GlutaMax, and $1 \mathrm{~mm}$ sodium pyruvate. After trituration, the cells were plated at a density of 130 cells $/ \mathrm{mm}^{2}$, which were precoated overnight at $4^{\circ} \mathrm{C}$ with $0.5 \mathrm{mg} / \mathrm{ml}$ poly-D-lysine in borate buffer. Once the cells had adhered to the substrate after $1 \mathrm{~h}$ in the plating media, the media was removed completely and replaced with Neurobasal media containing B-27 supplement and 0.5 mM GlutaMax. Cultures were grown for 5-14 DIV before fixation. When preparing a hippocampal primary culture, we optimize the procedure to obtain a relatively pure pyramidal culture. Glial cells in the brains provide many critical growth factors, hormones, and amino acids necessary for neuronal growth. We therefore supplement the media with B27, which optimizes growth and survival of hippocampal neurons without the need for a feeder layer of glial cells.

\section{Incubation protocols}

For the $6 \mathrm{~h} \mathrm{EtOH}$ treatment, the cells were incubated with $25 \mathrm{~mm} \mathrm{EtOH}$ and/or protein synthesis inhibitors in media at $37^{\circ} \mathrm{C}$, in parallel with controls. EtOH concentration levels were measured at the beginning and at the end of EtOH incubation with alcohol analogs (Analox). To maintain EtOH levels constant, $35 \mathrm{~mm}$ dishes with EtOH-treated cells were in a secondary container with an open $35 \mathrm{~mm}$ dish containing $25 \mathrm{~mm}$ EtOH in media. After the incubation protocols, the cells were live stained for GM1 and were fixed for immunocytochemistry afterward. Cells treated with Wnt3a (R\&D Systems) were serum deprived for $24 \mathrm{~h}$ before treatment to obtain the most consistent results.

\section{Immunocytochemistry}

In experiments for LSM confocal imaging, the cells were fixed after the incubation period with cold $4 \%$ PFA and $4 \%$ sucrose ( $15 \mathrm{~min}$ ), permeabilized with $0.3 \%$ Triton X-100 (5 min), blocked with 5\% BSA and 5\% normal donkey serum (30 $\mathrm{min}$ ), and incubated overnight with a polyclonal rabbit antibody against BK $\alpha$ subunit (1/500) (Alomone Labs, APC\#021 or APC\#107), followed by donkey anti-rabbit Cy3 secondary antibody (1/500) (Jackson ImmunoResearch Laboratories). Before permeabilization, we used Cholera toxin subunit B conjugated to Alexa-488 (labels the lipid raft ganglioside, GM1), as a membrane marker. The negative controls, performed without primary antibody incubation, showed no staining.

\section{Fixed imaging and analysis}

Confocal imaging was performed with an LSM 5 Pascal Confocal Microscope (Zeiss) using a $63 \times$ oil-immersion objective $(\mathrm{N} / \mathrm{A}=1.4)$. Imaging of each experiment was done the same day and imaging parameters were maintained between treatments. $z$-stacks through entire cells were taken, but analysis was done on single $z$-planes toward the middle of the cell. Image analysis was performed using ImageJ Software version $1.43 \mu$. One linescan was done per cell, from one membrane edge to the other. Plot profile (intensity of fluorescence over distance) data went through background subtraction and were then normalized to the peak of each plot profile. The first $5 \mu \mathrm{m}$ from the membrane edge was graphed as previously determined by GM1, membrane marker staining. Excel and the statistical analysis was done on GraphPad Prism. One-way ANOVA was used followed by a paired $t$ test for comparing the control group to only one treatment.

\section{Isolation of de novo synthesized proteins}

HEK293 cells stably transfected with hSlo $\alpha$, at $50 \%$ confluence, were placed in either fresh medium without $\mathrm{EtOH}$ (naive) or medium containing $25 \mathrm{~mm}$ EtOH (treatment). After $5.5 \mathrm{~h}$ of incubation, medium was replaced with methionine-free supplemented medium containing $50 \mu \mathrm{M}$ Click-IT AHA (L-Azidohomoalanine) working solution for the remaining $30 \mathrm{~min}$ of treatment with or without $\mathrm{EtOH}$, respectively. This was followed by isolation of newly synthesized proteins using the Click-iT 
protein enrichment kit (Invitrogen). Negative controls consisted of a naive preparation incubated in methionine- and AHA-free medium (null-controls)

\section{Cellular fractionation and immunoblotting}

At $4^{\circ} \mathrm{C}$, scraped HEK stably transfected hSlo $\alpha$ cells were homogenized using a homogenizing buffer (MES $0.5 \mathrm{M}, \mathrm{NaCl} 1 \mathrm{M}$, PMSF $200 \mathrm{~mm}$, and $\mathrm{Na}_{2} \mathrm{CO}_{3} 1 \mathrm{M}$ ) with 15 strokes in a Dounce homogenizer. A discontinuous sucrose density gradient was prepared by adjusting $2 \mathrm{ml}$ of the homogenate to $45 \%$ sucrose by addition of $2 \mathrm{ml}$ of $90 \%$ sucrose in MES buffered saline (MBS; $0.5 \mathrm{~m}$ MES, pH 6.5, $1 \mathrm{M} \mathrm{NaCl}$ ), and overlaying with $4 \mathrm{ml}$ of $35 \%$ sucrose in MBS containing $250 \mathrm{mM} \mathrm{Na}_{2} \mathrm{CO}_{3}$, and $4 \mathrm{ml} 5 \%$ sucrose in MBS containing $250 \mathrm{mM} \mathrm{Na}_{2} \mathrm{CO}_{3}$. The sample was centrifuged at 39,000 $\operatorname{rpm}(100,000 \times g)$ for $22 \mathrm{~h}$ at $4^{\circ} \mathrm{C}$. Twelve $1 \mathrm{ml}$ fractions were collected and centrifuged at $37,800 \mathrm{rpm}(100,000 \times \mathrm{g})$ for $30 \mathrm{~min}$ at $4^{\circ} \mathrm{C}$. Each fraction was resuspended in urea sample buffer, heated for $5 \mathrm{~min}$, loaded in a SDS-PAGE, and electrophoresed for $45 \mathrm{~min}$ at $175 \mathrm{~V}$ in a Mini Protean II (Bio-Rad Laboratories). The gel was transferred using a 3 (Bio-Rad Laboratories) at up to $25 \mathrm{~V}$ for $7 \mathrm{~min}$. The PVDF membranes were blocked with $3 \%$ nonfat milk and incubated overnight at $4^{\circ} \mathrm{C}$ with a primary antibody against BK hSlo $\alpha$ (Alomone Labs; 1:500), flotillin-1 (BD Biosciences; 1:1000), and caveolin-1 (Sigma; 1:2000). Subsequently, PVDF membranes were treated with secondary antibodies against rabbit or mouse (1:5000 dilution; Sigma-Aldrich).

\section{Electrophysiology}

Solutions. Patch pipettes were made of borosilicate glass (VWR Micropipettes) with 6-8 $\mathrm{M} \Omega$ resistances. In most cases, the tips of the patch pipettes were coated with Sigma-cote (Sigma-Aldrich). Free calcium concentrations were calculated using the WEBMAXC STANDARD program, at ionic strength of 0.16 and at $20^{\circ} \mathrm{C}$. Pipette and bath solutions were as follows (in $\mathrm{mM}$ ): $140 \mathrm{~K}$-gluconate, $5 \mathrm{Na}$-gluconate, 15 HEPES, 2 HEDTA, pH 7.35 (using $\mathrm{KOH}$ ) with $\mathrm{MgCl}_{2}$ and $\mathrm{CaCl}_{2}$ added to make free $1 \mathrm{~mm}$ and $1-10 \mu \mathrm{M}$, respectively. For whole-cell recordings, the pipette solution included the following (in $\mathrm{mm}$ ): 0.1 leupeptin, 12 phosphocreatine, $2 \mathrm{~K}$-ATP, and $0.2 \mathrm{Na}-\mathrm{GTP}$ to prevent rundown of the $\mathrm{Ca}^{+2}$ current.

Data acquisition. Data were acquired using a HEKA EPC10 patchclamp amplifier and a Macintosh-based computer system equipped with Pulse acquisition software (HEKA Electronik). When using the standard whole-cell patch-clamp recording method (Hamill et al., 1981), the membrane was depolarized to various potentials for $500 \mathrm{~ms}$ from a holding potential of $-60 \mathrm{mV}$. In whole-cell mode, series resistance did not exceed $20 \mathrm{~m} \Omega$ and was $60 \%$ compensated. Data were sampled at $25 \mu$ s per sample and filtered at $10 \mathrm{kHz}$ low bandpass. With this configuration, cells' capacitances were determined from the value of the amplifier's null of the whole-cell capacitive transients. The capacitances were used to define the current density as $\mathrm{pA} / \mathrm{pF}$. Mean BK current amplitude was measured at steady state, $450-490 \mathrm{~ms}$ after the beginning of the voltage step. Leak currents were subtracted using a scaled response from a pulse without a BK current. When recording single-channel activity, the inside-out patch-clamp configuration was used to precisely control the free intracellular calcium concentration (bath).

Analysis. Data analysis was performed with IgorPro graphing and curve fitting software (WaveMetrics). From whole-cell currents, normalized G-V plots were fitted using the sigmoidal function as follows:

$$
G / G_{\max }=\frac{1}{1+e^{k\left(V_{1 / 2}-V\right)}}
$$

Where $V_{1 / 2}$ is the half-activation voltage, $V$ the applied voltage, and $G_{\max }$ the maximum conductance of each plot. From single-channel recordings, NPo for each voltage was determined using the following:

$$
\text { NPo }=\frac{\sum_{i} i A_{i}}{\sum_{i} A_{i}}
$$

Where $N$ is the number of observed channels (levels), $i$ the ith level number, and $A_{i}$ the area of a Gaussian fit to the ith level's all-points- histogram from each recording. In the cases where the half-activation voltage $\left(V_{1 / 2}\right)$ was sought from NPo versus voltage curves, the values were determined from fits using the following:

$$
N P o=\frac{N}{1+e^{k\left(V_{1 / 2}-V\right)}}
$$

with the variables defined as above.

\section{Proteomics}

Newly synthesized proteins were isolated from HEK293 cells stably expressing hSlo $\alpha$ using the Click-iT protein enrichment kit (Invitrogen) and identified by tandem mass spectrometry (MS/MS). All MS/MS samples were analyzed using Mascot (Matrix Science; version 2.3.02) and X! Tandem (GPM, www.thegpm.org; version CYCLONE 2010.12.01.1). Scaffold (version 3.4.9, Proteome Software) was used to validate MS/MSbased peptide and protein identifications. Protein identifications were only accepted if they could be established at $>99.9 \%$ probability and contain at least 2 identified peptides. Ingenuity Pathway Analysis software identified possible connections and pathways based on the data obtained.

\section{Statistical comparisons}

In all cases, data are reported as mean \pm SEM; $n$ indicates the number of neurons or cells. Statistical analysis was performed using either a Student's $t$ test or a one-way ANOVA followed by a Dunnett's posttest unless otherwise stated. The criterion for significance in all cases was $p<0.05$.

\section{Results}

Primary cultured hippocampal neurons show protein synthesis-dependent decrease in BK channel current density in response to $6 \mathrm{~h} 25 \mathrm{~mm}$ alcohol exposure

Significant changes in BK channel current density had been observed in rat hypothalamic neurohypophysial (HNS) explants following a $6 \mathrm{~h} \mathrm{EtOH}$ exposure (Pietrzykowski et al., 2004) and more recently in hippocampal primary neurons (Palacio et al., 2015). Having found a persistent decrease in both current density and perimembrane (plasma membrane and/or the area adjacent to it) expression of endogenous BK channels in hippocampal neurons, our goal was to determine whether these changes required protein synthesis, as do other forms of prolonged neuronal adaptations involving learning and memory (McGaugh, 2000; Kelleher et al., 2004; Sutton and Schuman, 2006; Remaud et al., 2014). We first determined the basic electrophysiological properties, including voltage sensitivity and conductance, of BK single channels recorded from inside-out patches from cultured E18 hippocampal rat neurons. Single-channel currents were elicited by depolarizing the membrane from -60 to $80 \mathrm{mV}$ in $20 \mathrm{mV}$ increments while exposing the intracellular surface to different concentrations of $\mathrm{Ca}^{2+}(1,5$, and $10 \mu \mathrm{M})$. Single-channel activity was recorded at $-60 \mathrm{mV}$ to $20 \mathrm{in} 20 \mathrm{mV}$ increments with a bath concentration of $10 \mu \mathrm{M} \mathrm{Ca}^{2+}$. Increases in channel open probability are observed in relation to increasing calcium concentration (Wang et al., 2014). At $-60 \mathrm{mV}$, the channel displays an open probability $\left(\mathrm{NP}_{\mathrm{o}}\right)$ of $0.44 \pm 0.03$ in $10 \mu \mathrm{M}\left[\mathrm{Ca}^{2+}\right] ; 0.27 \pm$ 0.07 in $5 \mu \mathrm{M}\left[\mathrm{Ca}^{2+}\right]$ and $0.0013 \pm 0.06$ in zero $\left[\mathrm{Ca}^{2+}\right]$. Singlechannel conductances for all treatments in hippocampal neurons were determined for naive $(320.7 \pm 49.1 \mathrm{pS} ; n=18)$ and $6 \mathrm{~h}$ EtOH $25 \mathrm{~mm}(311.8 \pm 20.6 \mathrm{pS} ; n=8)$. These single-channel conductances are not statistically different from those measured when neurons were incubated with $10 \mu \mathrm{M} \mathrm{CHX} \mathrm{(316.9} \pm 14.2 \mathrm{pS}$; $n=12)$ and $6 \mathrm{~h} \mathrm{EtOH} 25 \mathrm{~mm}$ with $10 \mu \mathrm{M} \mathrm{CHX} \mathrm{(335.0} \pm 15.2 \mathrm{pS}$; $n=10)(p>0.05)$. 


\section{HEK293 stably expressing BK $\alpha$ mirrors EtOH effects in neurons: analysis of de novo synthesized proteins}

Having shown the decrease in current density in response to EtOH exposure was protein synthesis-dependent, we aimed to understand its molecular mechanism. Thus, we expanded to include a heterologous expression system to further probe the regulatory pathway involved. HEK293 cells offers a number of (technical) advantages, such as large quantity of cells that can be routinely harvested for proteomics and Western blot analysis, homogeneous expression of BK channels using a stably transfected cell line, purity of preparation (no glia), and the morphology of the cells allows for better voltage clapping during whole-cell patch clamp for current density measurements. Cell viability control experiments were done using DAPI DNA staining. DAPI is an impermeant DNA dye that can only stain live cells if their membrane is compromised. Therefore, nonviable cells can be discriminated as DAPI-positive and quantified as a faction of the total. No significant differences in cell viability were observed among EtOH treatments.

Using HEK293 cells stably expressing hSlo $\alpha$, we monitored the effectiveness of cycloheximide ( $\mathrm{CHX}$ ) as a general protein synthesis inhibitor by assaying all de novo protein synthesis with the Click-iT assay (Invitrogen). Click-iT technology uses AHA, an amino acid analog containing an azido moiety. The AHA is fed to cultured cells and incorporated into proteins during active protein synthesis. This is later detected with AlexaFluor-488alkyne (Invitrogen) or de novo synthesized proteins can be isolated using the Click-iT protein enrichment kit (Invitrogen). $\mathrm{CHX}$ inhibits general protein synthesis by interfering with the translocation step in synthesis via inactivation of transferase II, thus blocking translational elongation (Baliga et al., 1969). Block is rapid (observed within several minutes after exposure) but reversible. We performed the series of tests on HEK293 cells stably expressing hSlo $\alpha$ over three independent experiments $(N=$ 3 ) per condition. All percentages reported are expressed as percentage of control. We found that a concentration of $10 \mathrm{~nm}$ inhibits de novo protein synthesis in HEK293 to $51.32 \pm 7.49 \%$ $(n=22)$. After $10 \mu \mathrm{M} \mathrm{CHX,} \mathrm{protein} \mathrm{synthesis} \mathrm{decreases} \mathrm{to}$ $22.27 \pm 5.58 \%(n=11)$, and control $0.1 \%$ DMSO $100 \pm 10.39 \%$ $(n=23)$. Although other studies have indicated the effectiveness of nanomolar concentrations of CHX to block protein synthesis (Schneider-Poetsch et al., 2010), we found that for hippocampal primary neurons, micromolar concentrations were most effective in blocking $\beta$-catenin increases in response to EtOH (Fig. 1). This suggests that the overall effective concentrations of $\mathrm{CHX}$ in hippocampal neurons would likely be different from those measured for HEK293 cells. Although HEK293 cells have been shown to express some neuron-specific genes (Shaw et al., 2002; Lin et al., 2014), differences in protein turnover (synthesis and degradation) between neuronal and non-neuronal cells have been observed specifically in response to protein synthesis inhibitors (Tsvetkov et al., 2009), which may explain the requirement for higher concentration of CHX in hippocampal neurons.

As we have previously reported, current density measurements in hippocampus primary cultures are significantly reduced after $6 \mathrm{~h}$ EtOH exposure (Palacio et al., 2015). These effects are persistent beyond $18 \mathrm{~h} \mathrm{EtOH}$ withdrawal. We currently show that the reduction in current density due to $\mathrm{EtOH}$ can be blocked by coincubation with $10 \mu \mathrm{M}$ CHX (Fig. 1). Treatments with either protein synthesis inhibitor alone have no effect on either singlechannel conductance or $V_{1 / 2}$ determined by current voltage relationship. Hence, for the first time, we demonstrate that coincubation with protein synthesis inhibitors can block EtOH effects on the current density component of BK channel molecular tolerance.

\section{Current density decreases reflect functional hSlo $\alpha$ channel redistribution in response to $6 \mathrm{~h} \mathrm{EtOH}$ in stably transfected HEK 293 cells}

Decreased BK functional surface density is observed after $6 \mathrm{~h}$ EtOH exposure with both imaging and electrophysiology techniques in hippocampus primary cultured neurons (Palacio et al., 2015). Having also determined that the $6 \mathrm{~h}$ time point is critical in the development of persistent molecular tolerance (PMT) to EtOH (Velázquez-Marrero et al., 2011), we assessed whether this component of tolerance could be observed in HEK293 cells expressing the human BK channel ZERO isoform, hSlo $\alpha$. If so, this would replicate important aspects of this component with the human sequence of $\mathrm{BK}$ and further allow better experimental access to probe the mechanisms behind BK channel redistribution. Results with hSlo $\alpha$ are consistent with those observed previously, showing that current densities in cells treated for $6 \mathrm{~h}$ with $25 \mathrm{~mm} \mathrm{EtOH}$ are significantly lower than those measured for naive cells (Fig. 1). In cells from naive cultures, depolarizing the membrane from $-60 \mathrm{mV}$ to $100 \mathrm{mV}$ in increments of $20 \mathrm{mV}$ evoked increasingly strong hSlo $\alpha$ currents in the nA range. After $6 \mathrm{~h}$ in $25 \mathrm{~mm} \mathrm{EtOH}$, an identical voltage step protocol elicited $\sim 25 \%$ of the naive hSlo $\alpha$ current (Fig. $1 B$ ). When current was expressed as a function of membrane surface area (determined by membrane capacitance), we found a dramatic decrease in current density from $18.2 \pm 3.0 \mathrm{pA} / \mathrm{pF} ; n=4$ in naive cells to $5.7 \pm 2.0$ $\mathrm{pA} / \mathrm{pF} ; n=3$ after $6 \mathrm{~h} \mathrm{EtOH} \mathrm{(} p \geq 0.05)$. These changes, like those observed in hippocampal primary neurons, were not attributable to changes in BK total protein expression, suggesting that changes in current density reflect redistribution of channels away from the plasma membrane. Unlike hippocampal neurons, HEK293 cells stably expressing hSlo $\alpha$ showed no decrease in current density in response to $3 \mathrm{~h}$ exposure (Fig. $1 B$ ). This suggests subtle differences in the time-points of EtOH-induced BK channel redistribution in hippocampal neurons, despite their key similarities with transfected HEK cells after $6 \mathrm{~h} \mathrm{EtOH}$ exposure. No changes were observed in current density in either HEK cells or hippocampal neurons after coincubation with EtOH (25 mM) and CHX (10 nM in HEK and $10 \mu \mathrm{M}$ in hippocampal; $p \leq 0.05$; $n=4)$. These data support the interpretation that internalization of the $\mathrm{BK}$ channel in response to $\mathrm{EtOH}$ for both hippocampal neurons and HEK cells is protein synthesis-dependent.

\section{Immunocytochemistry of $\alpha \mathrm{BK}$ channels indicates a redistribution in response to $6 \mathrm{~h} \mathrm{EtOH}$}

Once current density decrease of BK channel was determined, it was important to measure BK channel expression patterns via immunofluorescence in response to EtOH (Figs. 2, 3). This would further allow us to differentiate between changes in channel function and actual internalization due to EtOH. To image BK channels, we used confocal microscopy, as our previous studies comparing confocal and TIRF imaging (data not shown) establishing comparable results both showing internalization of BK in hippocampus neurons (Palacio et al., 2015), despite affording less membrane resolution. To quantify surface BK labeling by confocal imaging, we used line scans and GM1 staining, as a membrane marker, to identify the surface. Quantification of immunofluorescence showed that there was a significant decrease of $38.0 \pm 13.8 \%(p<0.01)$ in BK labeling at the membrane area after $6 \mathrm{~h}$ of EtOH exposure compared with the untreated control. However, when the cells were coincubated with CHX, the surface 
A
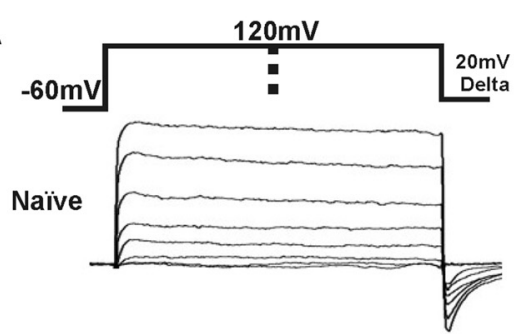

EtOH

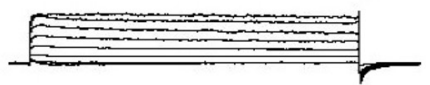

$500 \mathrm{pA}$

$100 \mathrm{~ms}$

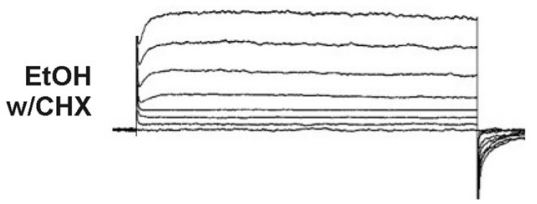

B

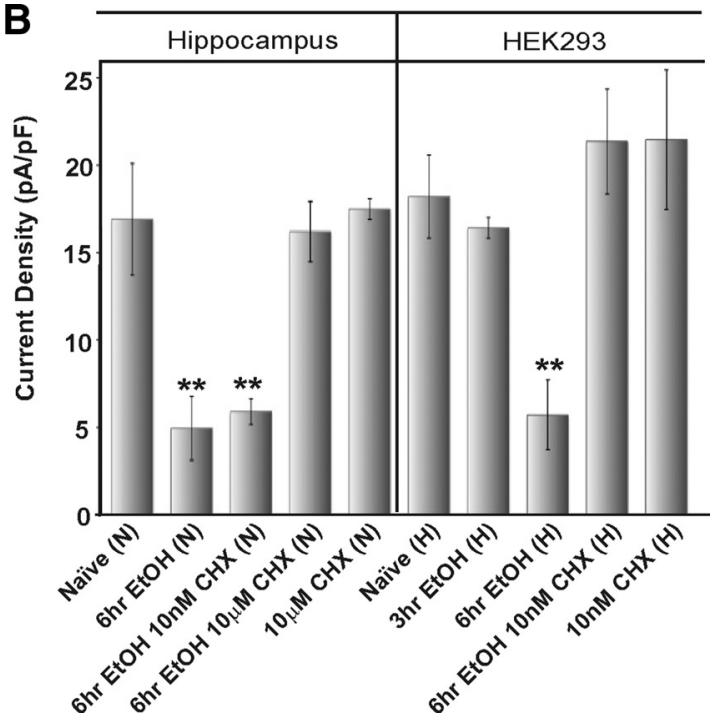

Figure 1. Decrease in current density after $6 \mathrm{~h} \mathrm{EtOH}$ before exposure is blocked during cycloheximide (CHX) coincubation. BK currents in neuronal cultures were recorded in whole-cell patch clamp to determine current densities. $A$, Representative currents; membrane potential was held at $-60 \mathrm{mV}$ and depolarized for $5 \mathrm{~s}$ from -60 to $200 \mathrm{mV}$ in $20 \mathrm{mV}$ increments. $\boldsymbol{B}$, Bar graph representing average current densities ( \pm SEM) recorded for naive $(n=5), 6 \mathrm{~h} \mathrm{Et0H}(n=8), 6 \mathrm{~h} \mathrm{EtOH}$ with $10 \mathrm{~nm} \mathrm{CHX}(n=4), 6 \mathrm{~h} \mathrm{EtOH}$ with $10 \mu \mathrm{M} \mathrm{CHX} \mathrm{(} n=4)$, and $10 \mu \mathrm{M} \mathrm{CHX} \mathrm{(n=7)} \mathrm{hippocampal} \mathrm{neurons}$ showing $6 \mathrm{~h} \mathrm{EtOH}$ was significantly reduced ( $\sim 5$-fold) as compared to naive. ${ }^{* *} p \leq 0.01$. HEK293 cells stably expressing BK ( \pm SEM) were recorded from naive $(n=8), 3 \mathrm{~h} \mathrm{EtOH}(n=5), 6 \mathrm{~h} \mathrm{EtOH}$ $(n=5), 6 \mathrm{~h}$ EtOH with $10 \mathrm{~nm} \mathrm{CHX}(n=5)$, and $6 \mathrm{~h} 10 \mathrm{~nm} \mathrm{CHX}(n=6)$ treated cells showed $6 \mathrm{~h}$ EtOH was significantly reduced ( $\sim 5$-fold) as compared to naive. Asterisks represent statistical differences $(p \leq 0.01)$.

A
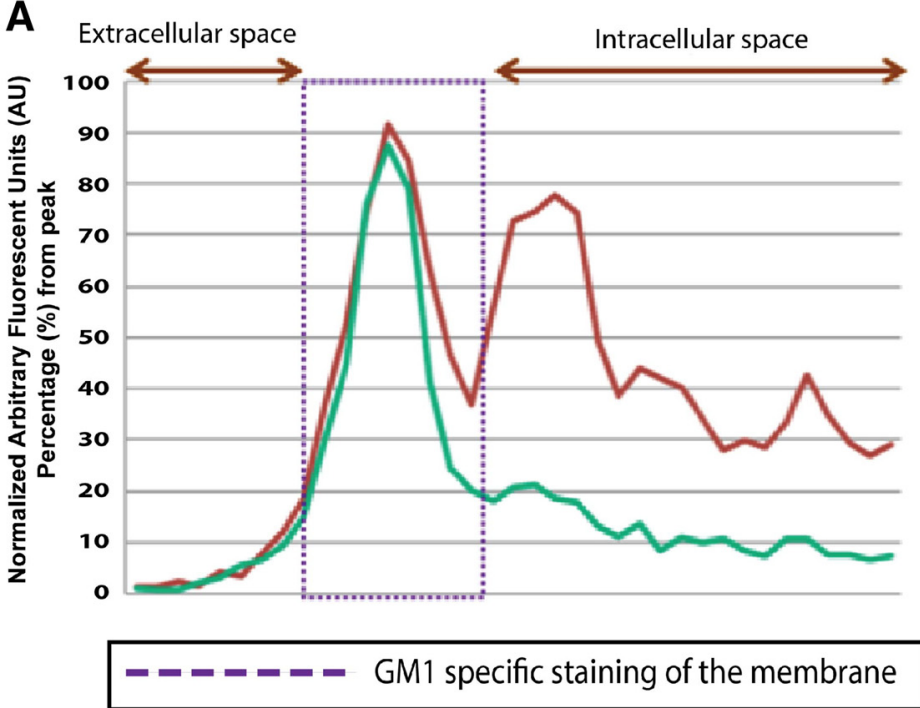

B

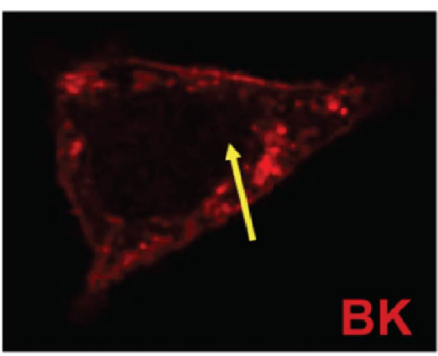

C

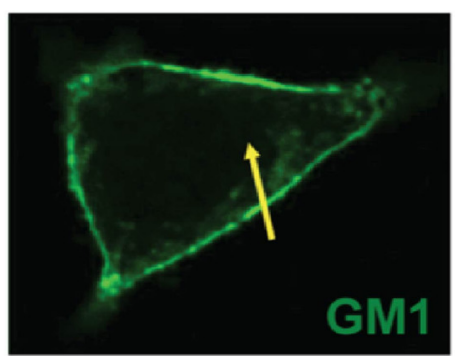

Figure 2. Normalized staining distribution: BK and GM1 (monosialotetrahexosylganglioside). $\boldsymbol{A}$, Graph representing normalized plot profiles of BK $\alpha$-subunit (red) and GM1 (green), as a membrane marker, from the same cell. Images represent the line scans (yellow arrows) through the cell both in the red and green channels. $\boldsymbol{B}$, Sample HEK293 marked by BK $\alpha$ staining (red) is present at the membrane and within the cell. C, GM1staining (green) showing membrane labeling and only background levels of GM1 labeling inside the cell. levels of BK were comparable with the untreated control with a $10.8 \pm 16.1 \%$ change compared with untreated control $(p=$ 0.50 ). The difference between the $\mathrm{EtOH}$ and the ETOH/CHX treatment was statistically significant $27.2 \pm 11.4 \%(p<0.05)$. Intracellular BK labeling was not significantly changed when CHX was present $19.5 \pm$ $15.8 \%$ compared with untreated control $(p=0.2)$. Figure 3 shows the quantification results for surface expression. The immunofluorescence data demonstrate that the BK channel is internalized in transfected HEK293 cells after $6 \mathrm{~h}$ exposure to EtOH. Moreover, coincubation with a protein synthesis inhibitor prevented this internalization from occurring, suggesting that internalization is dependent on de novo protein synthesis in transfected HEK cells.

Western blot analysis and cell fractionation indicate a redistribution of BK channels

To further determine whether the changes that we measured at the plasma membrane represented a redistribution of BK channels to the cytoplasm (internalization) or whether these changes were caused by a downregulation of the total amount of BK channel expression after EtOH exposure, we performed Western blot analysis after all treatments. Western blots from three independent experiments, done in duplicate in both primary hippocampal neurons and HEK cells stably expressing hSlo $\alpha$, show no significant change $(p \geq 0.1)$ in total hSlo $\alpha$ 
A
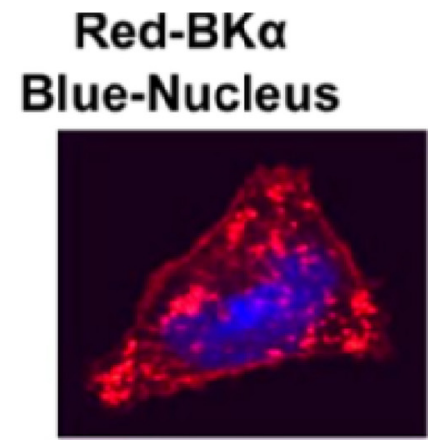

Control 6h

EtOH 6hr

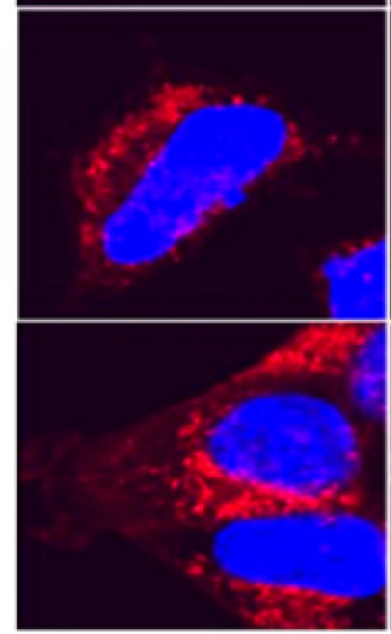

.

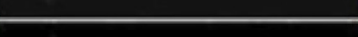

BKa

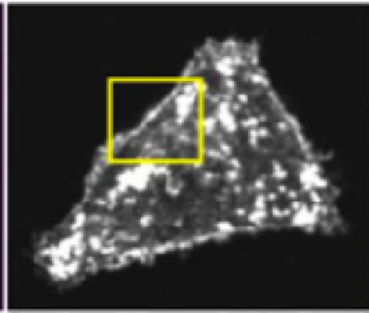

Pseudo Color

Intensity Scan
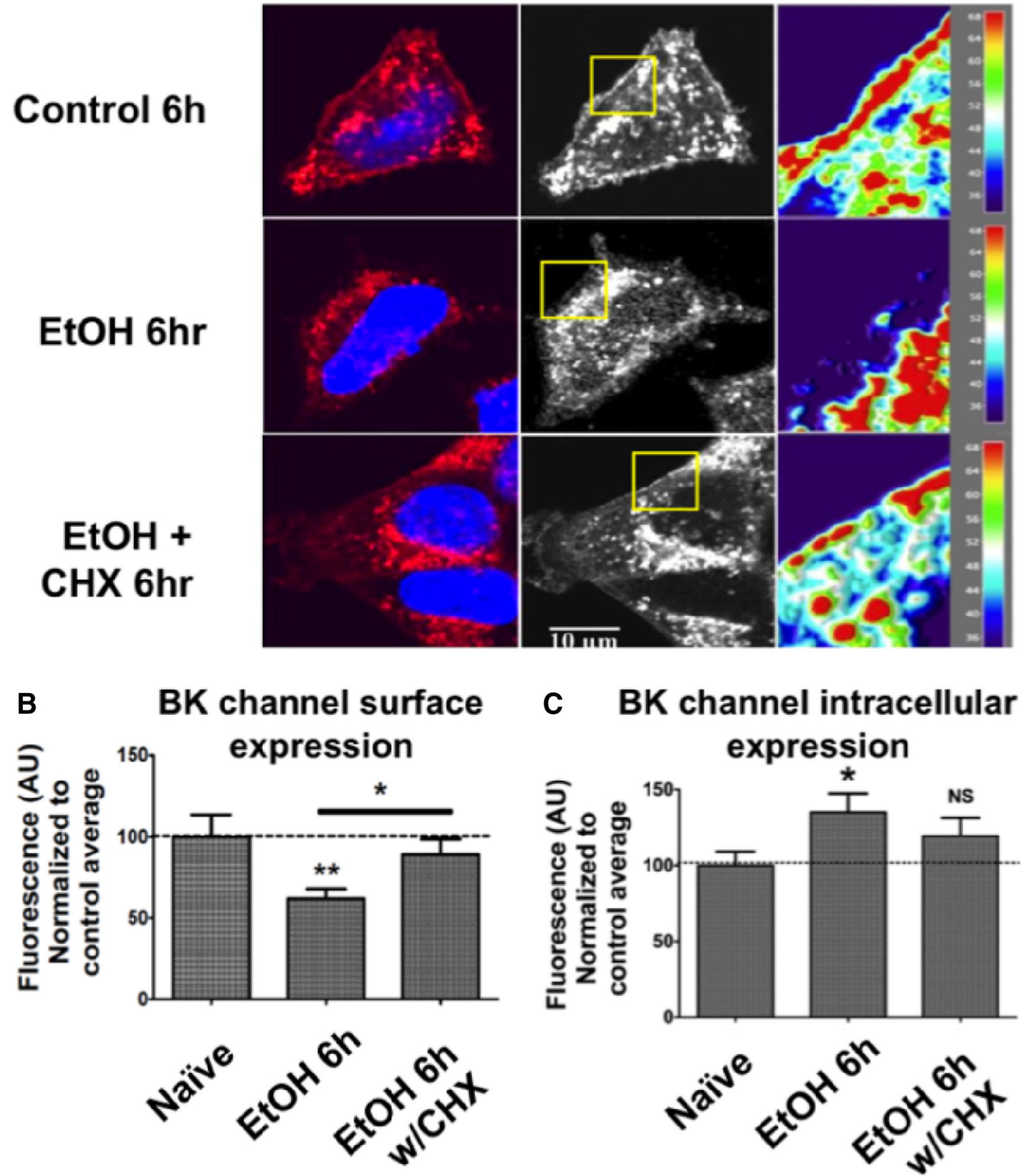

Figure 3. Immunocytochemical localization of the BK channel in HEK293 cells with respect to the membrane edge. A, Intensity profile of representative images with BK $\alpha$ subunit staining. Zoomed area represents pseudo-colored intensity profile. Red represents highest fluorescent intensity. Blue represents lowest fluorescent intensity. EtOH-treated cells show highest fluorescence away from the membrane compared with control and EtOH/CHX groups. Merged images represent BK staining in red and DAPI (depicting the nucleus) in blue. Quantification of fluorescent staining normalized to fluorescent arbitrary units as percentage control (\%). B, Values for the membrane area were averaged and plotted for each condition. $\boldsymbol{C}$, The values of the line scans pertaining to the intracellular portion of the cell were averaged and plotted for each condition. Asterisk represents statistical differences $(p \leq 0.05) . N=32-41$ cells per treatment, over 3 independent experiments. Black line with star indicates a statistical difference between two treatment groups. Error bars indicate \pm SEM.

BK channel protein expression levels (data not shown) after treatment with 6 h $25 \mathrm{~mm}$ EtOH with or without coincubation with $\mathrm{CHX}$ nor with CHX alone. These findings corroborate the immunocytochemical results showing no change in BK protein expression, only changes in distribution (Fig. 3). This suggests two important points: (1) the rate of BK channel protein turnover is likely relatively slow for both HEK 293 cells and hippocampal pyramidal neurons and thus not targeted by protein synthesis inhibition within the time span/ concentration used, or alternatively, not targeted by these pharmacological blockers; and (2) given no significant change in total BK protein, decreases in current density reflect changes in channel surface expression.

There is a well-documented association between potassium voltage-gated channels and lipid rafts (Martens et al., 2000, 2004; 

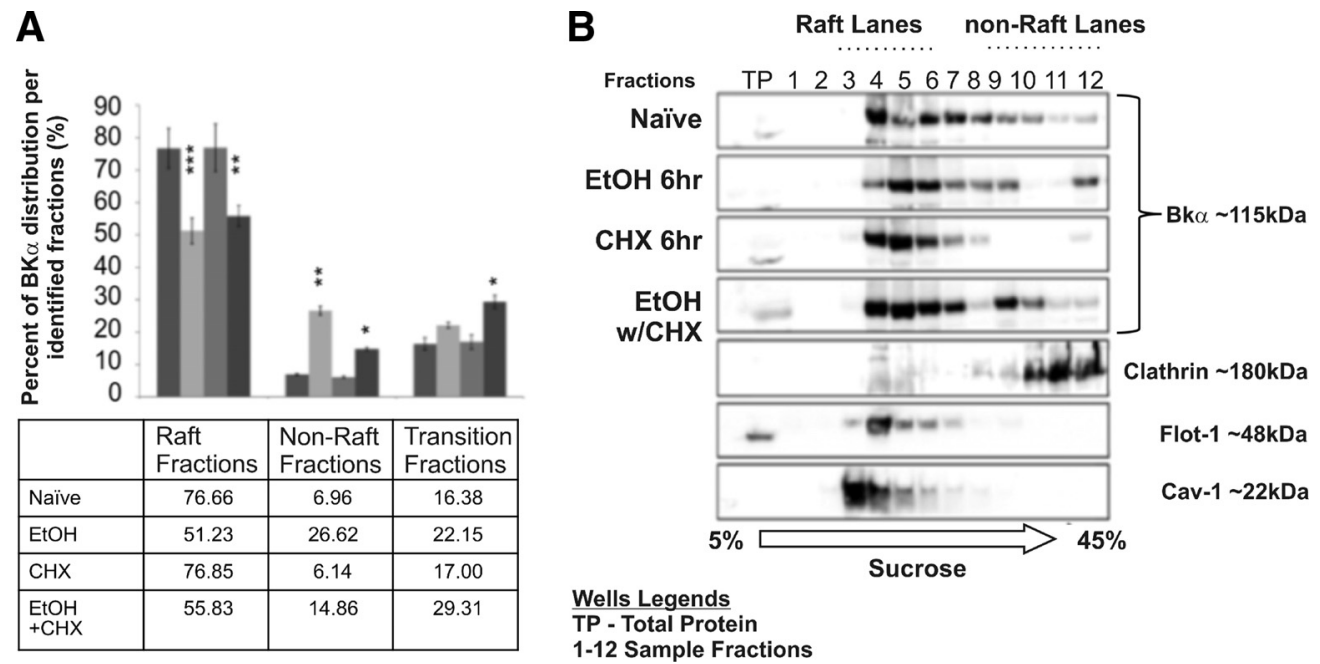

Figure 4. Western blot of HEK stably transfected hSlo cell fractionation using sucrose gradient with $\mathrm{Na}_{2} \mathrm{CO}_{3}$. Immunoblot fractionation showed the presence of bands of BK $\alpha$ between the fourth and sixth fraction. $A$, Quantification of fractions for each of five treatments: naive, $6 \mathrm{~h} 25 \mathrm{~mm} \mathrm{EtOH,} 6 \mathrm{~h} 10 \mathrm{~nm}$ CHX, and $6 \mathrm{~h} 25 \mathrm{~mm}$ EtOH coincubated with $10 \mathrm{~nm}$ CHX. The fractions are quantified as within-lipid raft fractions, in transition and nonlipid raft. Significant statistical differences were found between naive and EtOH-exposed and naive and EtOH w/CHX for both $\mathrm{BK}$ channels cofractionating with lipid rafts and nonraft fractions. Within transition fractions, only EtOH with CHX is statistically different from naive. $\boldsymbol{B}$, Representative bands cofractionated with flotillin- 1 and caveolin-1, which are membrane raft markers. After $25 \mathrm{~mm}$ EtOH exposure for $6 \mathrm{~h}$, the BK $\alpha$ band redistributes to nonmembrane rafts higher fractions $(9-12)$. These experiments represent $N=4$ separate experiments each run in triplicate. ${ }^{*} p \leq 0.05$ (two-way ANOVA plus Tukey's Test). ${ }^{* *} p \leq 0.01$ (two-way ANOVA plus Tukey's Test). ${ }^{* * *} p \leq 0.001$ (two-way ANOVA plus Tukey's Test).

Szabò et al., 2004). Lipid rafts are cholesterol- and sphingolipidenriched plasma membrane domains (Simons and Ikonen, 1997; Wu et al., 2013). BK channels have been observed to associate with lipid rafts (Tajima et al., 2011; Dopico and Bukiya, 2014) and can be found in clusters likely coupled to lipid raft scaffolding (Dalskov et al., 2005; Dopico et al., 2012; Pristerà et al., 2012; Palacio et al., 2015). Our recent studies have shown that declustering occurs in hippocampal pyramidal neurons in response to $6 \mathrm{~h} 25 \mathrm{~mm}$ EtOH exposure likely associated to persistent channel internalization (Palacio et al., 2015). This is characterized by a decrease in the fluorescence intensity of individual clusters also observed within the HNS after EtOH exposure (Pietrzykowski al., 2004). Interestingly, cluster size does not correlate with internalization before the $6 \mathrm{~h}$ EtOH exposure time point in hippocampal neurons, suggesting alternate mechanisms for BK channel trafficking at $3 \mathrm{~h} \mathrm{EtOH}$ exposure. This "switch" in regulation is reminiscent of that observed in striatal neurons causing persistent desensitization of $\mathrm{BK}$ channels to $\mathrm{EtOH}$ only after $6 \mathrm{~h}$ exposure but not 3 h (Velázquez-Marrero et al., 2011).

Using sucrose gradient centrifugation, BK channel distribution was assessed in relation to lipid rafts within HEK 293 membrane fractions. After $6 \mathrm{~h}$ with $25 \mathrm{~mm}$ EtOH treatment, $\sim 73.85 \%$ of the BK protein shifts toward higher fractions associated with nonlipid raft membranes determined by clathrin (nonlipid raft marker) labeled fractions (Fig. $4 A, B$ ). These experiments represent $N=4$ separate experiments, each run in triplicate. Although this does not directly establish internalization of the BK channel, it does indicate a change in BK channel membrane distribution away from lipid raft fractions likely associated to channel declustering within the plasma membrane. However, cofractionation may be a result of several alternative associations present in fractions containing lipid rafts (Pike, 2009). We have limited the amount of artifacts typically incurred with detergent extraction by purification of detergent-free lipid rafts. However, one significant concern is that membrane fractions enriched in cholesterol and lipid raft markers, such as caveolin and flotillin, may still contain membrane contaminants from nonraft or intracellular membranes. Proteins associated to these contaminants may thus appear in lipid raft fractions without any direct association to them.

Proteomic analysis of de novo synthesized proteins further shows an upregulation of clathrin interactor-1 protein (Table 1) when treated with $6 \mathrm{~h} \mathrm{EtOH}$. This further supports the idea that a clathrin-mediated endocytic pathway may be involved in subsequent BK channel internalization. It is important to note that treatment with $\mathrm{CHX}$ alone does not affect the proportion of $\mathrm{BK}$ channels in nonlipid raft fractions, whereas coincubation of $\mathrm{CHX}$ and $\mathrm{EtOH}$ results in a $53.16 \%$ increase of nonlipid raft-associated BK (Fig. 4). The data suggest a nonprotein synthesis-dependent component involved in $\mathrm{EtOH}$ redistribution of BK channels within membranes, characterized by movement away from lipid rafts in response to $6 \mathrm{~h}$ EtOH exposure.

Isolation and identification of de novo synthesized proteins The requirement for protein synthesis in EtOH-induced BK channel redistribution led us to identify candidate proteins selectively upregulated in synthesis during the $6 \mathrm{~h} \mathrm{EtOH}$ incubation period. For this purpose, we used the Click-iT ${ }^{2011}$ Protein Enrichment Kit, with improved detection allowing isolation of low abundant proteins and compatibility with mass spectrometry techniques, making it an excellent approach for these studies. We used this technique for tagging, isolating, and identifying de novo synthesized proteins in response to different exposures of alcohol. Newly synthesized proteins were isolated using the kit during the last hour of the $6 \mathrm{~h} \mathrm{EtOH}$ exposure from HEK293 cells stably expressing hSlo $\alpha$ channels. They were identified by MS/MS and Western blot analysis. Of the proteins screened, 737 were positively identified, of which 145 showed a significant increase in spectral counts after EtOH incubation. All MS/MS samples were analyzed using Mascot (Matrix Science; version 2.3.02) and X! Tandem (GPM; version CYCLONE 2010.12.01.1) search algorithms routinely selected for their proven specificity and confidence of identification (Perkins et al., 1999; Craig et al., 2004). In our study, we only used peptide matches that met a probability of correct identification of $99.9 \%$ for each unique peptide sequence identified and contained at least 2 unique identified sequences. 
Table 1. Sample of de novo synthesized proteins isolated from stably transfected HEK293 cells expressing hSlo $\alpha$ after 6 h ethanol incubation ${ }^{a}$

\begin{tabular}{|c|c|c|c|c|c|c|c|}
\hline Protein & Gene_human & Accession number & Biological function & EtOH & Naive & Null & EtOH/naive \\
\hline $\mathrm{Ca}^{2+}$ activated $\mathrm{K}$ channel subunit $\alpha-1$ & KCNMA1 & Q28204 & $\begin{array}{l}\text { Potassium channel activated by both membrane } \\
\text { depolarization or increase in cytosolic } \mathrm{Ca}^{2+} \text { that } \\
\text { mediates export of } \mathrm{K}^{+}\end{array}$ & 13 & 15 & 3 & 0.9 \\
\hline Catenin $\beta-1$ & CTNB1 & P35222 & $\begin{array}{l}\text { Key downstream component of the canonical Wnt } \\
\text { signaling pathway }\end{array}$ & 14 & 7 & 0.5 & 2.0 \\
\hline Spectrin $\beta$ chain & SPTB2 & Q01082 & $\begin{array}{l}\text { Involved in secretion, interacts with calmodulin in a } \\
\text { calcium-dependent manner, and is thus a } \\
\text { candidate for the calcium-dependent movement } \\
\text { of the cytoskeleton at the membrane }\end{array}$ & 22 & 9 & 7 & 2.4 \\
\hline Amyloid-like protein 2 & APLP2 & Q06481 & $\begin{array}{l}\text { May play a role in the regulation of hemostasis; the } \\
\text { soluble form may have inhibitory properties toward } \\
\text { coagulation factors }\end{array}$ & 10 & 6 & 2 & 1.7 \\
\hline Clathrin interactor 1 & EPN4 & Q14677 & $\begin{array}{l}\text { Binds to membranes enriched in phosphatidylinositol } \\
\text { 4,5-bisphosphate (Ptdlns(4,5)P2); may have a role } \\
\text { in transport via clathrin-coated vesicles from the } \\
\text { trans-Golgi network to endosomes; stimulates } \\
\text { clathrin assembly }\end{array}$ & 9 & 3 & 1 & 3.0 \\
\hline Junction plakoglobin & PLAK & P14923 & $\begin{array}{l}\text { Common junctional plaque protein; can replace } \\
\beta \text {-catenin in E-cadherin/catenin adhesion } \\
\text { complexes, which are proposed to couple cadherins } \\
\text { to the actin cytoskeleton }\end{array}$ & 32 & 21 & 14 & 1.5 \\
\hline mRNA export factor & RAE1L & P78406 & $\begin{array}{l}\text { Binds mRNA; may function in nucleocytoplasmic } \\
\text { transport and in directly or indirectly attaching } \\
\text { cytoplasmic mRNPs to the cytoskeleton }\end{array}$ & 6 & 4 & 0 & 1.5 \\
\hline Coatomer subunit $\beta$ & $\mathrm{COPB}$ & P53618 & $\begin{array}{l}\text { The coatomer is a cytosolic protein complex that binds } \\
\text { to dilysine motifs and reversibly associates with } \\
\text { Golgi non-clathrin-coated vesicles, which further } \\
\text { mediate biosynthetic protein transport from the ER, } \\
\text { via the Golgi up to the trans-Golgi network }\end{array}$ & 12 & 5 & 1 & 2.4 \\
\hline Polyadenylate-binding protein 1 & PABP1 & P11940 & Binds the poly $(A)$ tail of mRNA & 35 & 28 & 9 & 1.3 \\
\hline Clusterin & CLUS & P10909 & $\begin{array}{l}\text { Extracellular chaperone that prevents aggregation of } \\
\text { non-native proteins }\end{array}$ & 6 & 4 & 0 & 1.5 \\
\hline Probable ATP-dependent RNA helicase DDX5 & DDX5 & P17844 & $\begin{array}{l}\text { Involved in the alternative regulation of pre-mRNA } \\
\text { splicing }\end{array}$ & 34 & 27 & 7 & 1.3 \\
\hline BCL-6 corepressor & BCOR & Q6W2J9 & Transcriptional corepressor & 6 & 2 & 0 & 3.0 \\
\hline
\end{tabular}

${ }^{a}$ Summed unique peptide count control (naive), $25 \mathrm{mM}$ ethanol and null (no AHA control) all after $6 \mathrm{~h}$ incubation. Ratio of ethanol to naive highlights fold differences in peptide detection for each protein.

However, this method does not accurately quantify peptide concentration, and any list of proteins generated must be further validated (Johnson et al., 2005). This is typically done through Western blot analysis. For the purposes of this study, MS/MS was used to identify a list of possibly upregulated de novo synthesized proteins in two separate experiments $(N=2)$ each run in triplicate. Validation and quantification were accomplished by Western blot analysis with $N \geq 3$, also individually run in triplicate.

Of the proteins found to have increased spectral counts during EtOH treatment, with low nonspecific peptide counts (null control) and a role in BK channel surface expression was CTNNB1, catenin (cadherin-associated protein) $\beta_{1}$, an $88 \mathrm{kDa}$ protein (Table 1) (De Ferrari and Moon, 2006). The $\beta$-catenin spectral count was found to be increased by twofold after $6 \mathrm{~h} \mathrm{EtOH}$ exposure (Fig. 5A; Table 1). Both Western blot analysis of HEK stably expressing hSlo $\alpha$ (Fig. $5 B$ ) and hippocampus primary cultures show a significant increase in $\beta$-catenin in response to $6 \mathrm{~h} \mathrm{EtOH}$ exposure (Fig. 5D,E). Western blot analysis after $25 \mathrm{~mm} \mathrm{EtOH}$ exposure showed the total amount of $\beta$-catenin increased significantly during $1 \mathrm{~h}(206.05 \pm 30.44 \% ; n=6), 3 \mathrm{~h}(194.57 \pm$ $35.22 \% ; n=7)$, and $6 \mathrm{~h}(191.53 \pm 10.08 \% ; n=3)$. Interestingly, values returned to close to preexposure levels after $24 \mathrm{~h}$ of EtOH exposure $(117.7 \pm 5.7 \% ; n=4)$. Primary hippocampal cultures showed a more modest yet significant increase in $\beta$-catenin (na- ive, $100.00 \pm 11.97 \%$; and $154.69 \pm 9.20 \%$ in the presence of 25 $\mathrm{mm}$ EtOH) (Fig. $5 D, E$ ). The rise in $\beta$-catenin was blocked when EtOH was coincubated with $10 \mathrm{~nm} \mathrm{CHX} \mathrm{in} \mathrm{HEK293} \mathrm{cells} \mathrm{(data}$ not shown) or $10 \mu \mathrm{M}$ CHX in hippocampal neurons (Fig. 5D,E). Several studies have indicated that activation of the canonical $\mathrm{Wnt} / \beta$-catenin signaling pathway leads to the accumulation of both cytoplasmic and subsequent nuclear $\beta$-catenin. This occurs upon Wnt-signaling activation, when the ability of glycogen synthase kinase-3 (GSK-3) to phosophorylate $\beta$-catenin's amino serine/threonine phosophorylation site is impaired, and thus $\beta$-catenin is no longer targeted for degradation via ubiquitination. The rate of $\beta$-catenin synthesis, in response to $\mathrm{EtOH}$, is significantly decreased in the presence of CHX supporting the idea that accumulation of $\beta$-catenin is important in mediating $\mathrm{BK}$ channel redistribution in response to $\mathrm{EtOH}$. Interestingly, in mouse fibroblast L-cells, the use of $100 \mu \mathrm{g} / \mathrm{ml} \mathrm{CHX} \mathrm{w/Wnt3a}$ does not significantly deviate from baseline $\beta$-catenin concentrations even after $400 \mathrm{~min}$ (6.7 h) of treatment (Hannoush, 2008). This suggests that both the rate of synthesis and degradation of $\beta$-catenin are relatively slow when Wnt-signaling is not active. Therefore, we might expect that treating pyramidal neurons with $\mathrm{CHX}$ will be effectively targeting any changes in baseline concentration of $\beta$-catenin due to increased translation in response to $\mathrm{EtOH}$ exposure. Our results support this hypothesis. 
A

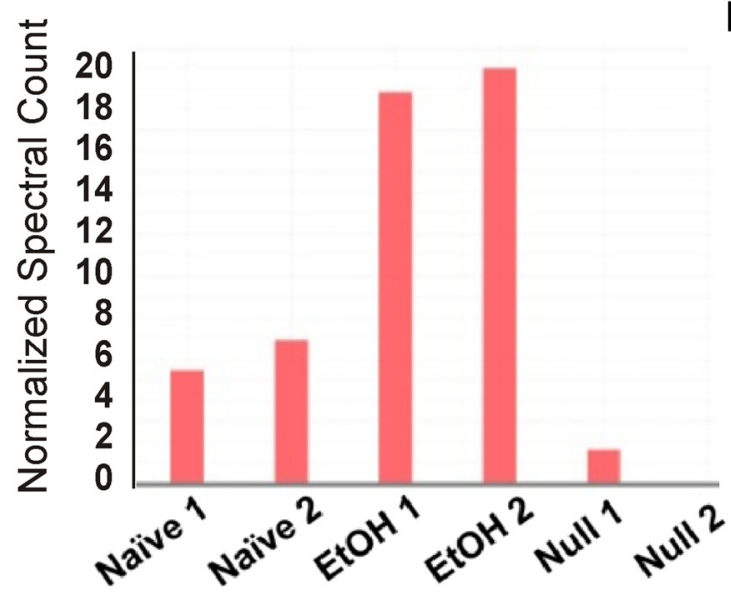

B

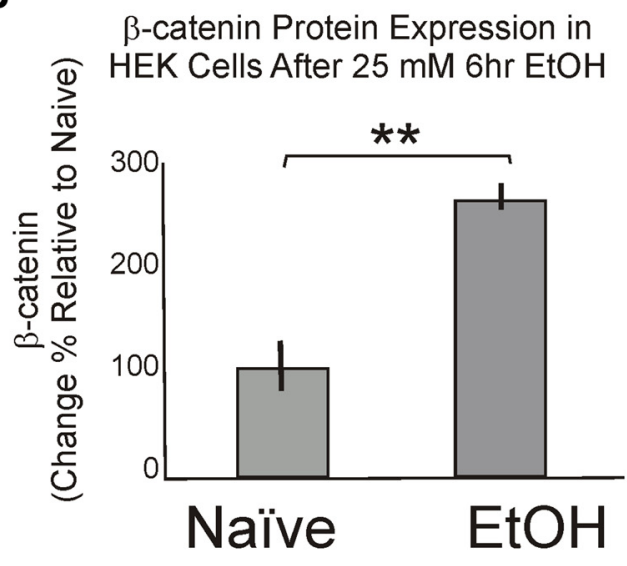

CTNB1_HUMAN (100\%), 85,497.0 Da

Catenin beta- 1 OS=Hoo sapiens $\mathrm{GN}=\mathrm{CTNNB} 1 \mathrm{PE}=1 \mathrm{SV}=1$

8 unique peptides, 9 unique spectra, 17 total spectra, 217/781 amino acids (28\% coverage)

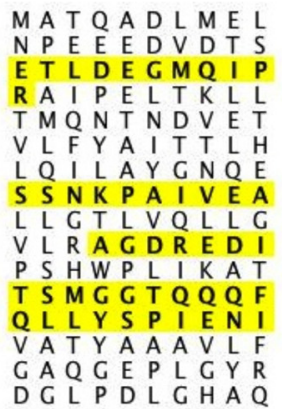

D M A M E P D R K A Q V L Y E W E Q G F S T Q F D A A H P T NDEDQ V V V N K A R C T A G T L H N N L L L H Q E G A K S K L I I L A S G G G G M Q A L G L H L S D D I N V V T C A

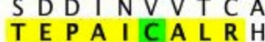
$V G L I R N L A L C$ VE G V R M E I V Q R V A A G V L C E R M S E K P Q D Y OD P S Y R S F H

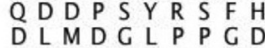

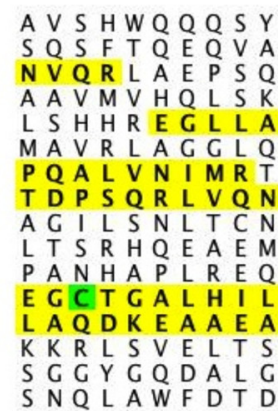

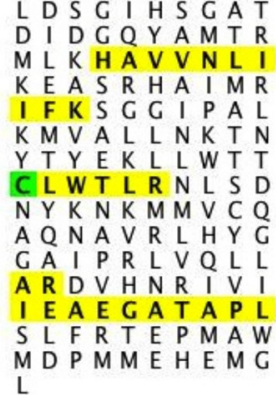

T T A P S L S G K G A Q R V R A A M P N Y Q D D A E L A T $S P Q M V S A$ I V R V K M L G S P D S $V K F L A$ I T T D C S R V L K V L S V C A A T K Q E G M E G $V G C I E A L V R T$ L P V V V K L L H P VRAHQDTQR R R G L N T I P L F V TEL L S R N E $N E T A D L G L D$ I G H H P G D Y P V
D

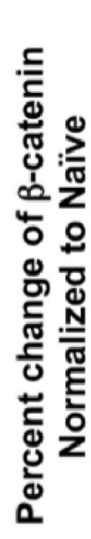

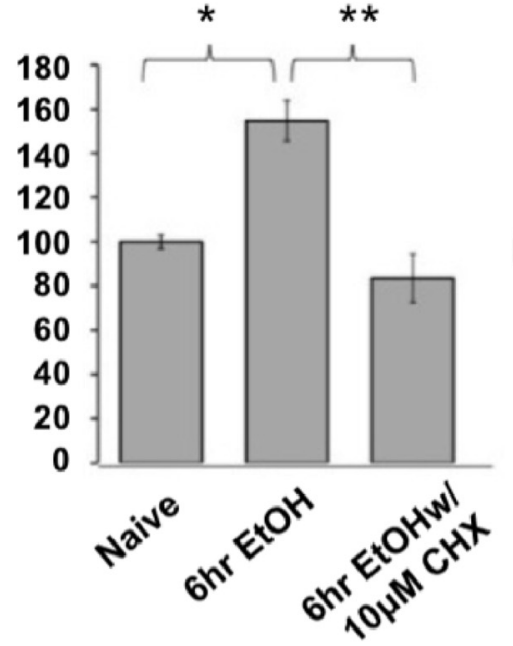

E

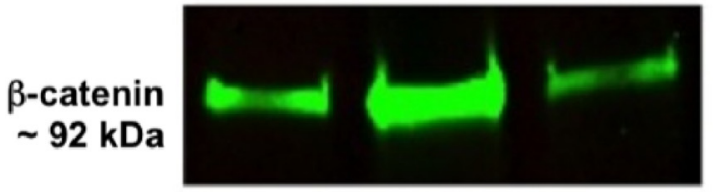

Anti-

GAPDH

$\sim 37 \mathrm{kDa}$

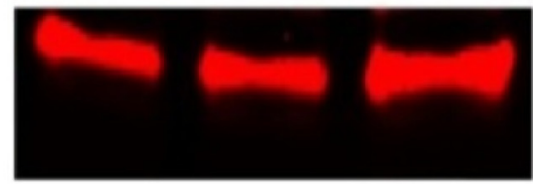

Figure 5. Spectral count analysis of $\beta$-catenin from naive (C1 and (2), EtOH (E1 and E2), and Null (N1 and N2 = no AHA-control) incubated for $6 \mathrm{~h}$ verified with Western blot analysis. $\boldsymbol{A}$, Normalized spectral count of de novo synthesized $\beta$-catenin under naive, $6 \mathrm{~h}$ EtOH exposure, and no-AHA (null) control samples Each sample was run in duplicate ( $N=2$ ). $\boldsymbol{B}$, Immunoblot of total protein was evaluated after $25 \mathrm{~mm}$ EtOH exposure for $6 \mathrm{~h}$, revealing the presence of $\beta$-catenin at its expected molecular weight ( $\sim 92 \mathrm{kDa}$ ). GAPDH (MW $\sim 37 \mathrm{kDa}$ ) was used as an internal control $(N=3)$, representing the number of individual experiments. ${ }^{* *} p \leq 0.01$. C, Unique peptide sequence of CNTB1_HUMAN. Highlighted regions are sequence regions specifically recognized by Scafflold Analysis Software. Analysis recognized 8 unique peptides, 9 unique spectra, 17 total spectra, and 217 of 781 amino acids (28\%). Green highlighted regions represent $95 \%$ probability of correct identification. Western blot of HEK stably transfected hSlo cells for $\beta$-catenin protein expression. $D$, Western blot analysis of hippocampal pyramidal neurons in culture. Graph represents data normalized to GAPDH. Relative expression to naive control expressed as percentage of control. Naive conditions $(100.00 \pm 3.06 \%), 6 \mathrm{~h} \mathrm{EtOH}(154.69 \pm 9.20 \%)$, and $6 \mathrm{~h} \mathrm{EtOH}$ with $10 \mu \mathrm{M}$ CHX $(83.53 \pm 10.94 \%)$ data are reported as mean \pm SEM. $N=3$, representing the number of individual experiments all done in triplicate. Asterisks represent statistical differences $\left({ }^{*}, p \leq 0.05 ;{ }^{* *}, p \leq 0.01\right)$. $\boldsymbol{E}$, Representative Western blot gel labeled for $\beta$-catenin and GAPDH. 
Wnt/ $\beta$-catenin signaling is both necessary and sufficient for BK channel membrane surface redistribution in response to $6 \mathrm{~h} \mathrm{EtOH}$ exposure

A previous study by Bian et al. (2011) showed a critical role for $\beta$-catenin and hSlo $\alpha$ channel interactions in modulating hSlo $\alpha$ surface expression. In agreement with this study, we found that $1 \mathrm{~h}$ treatment with $200 \mathrm{ng} / \mathrm{ml} \mathrm{Wnt3a} \mathrm{ligand,}$ which activates the Wnt FZD receptor endogenously expressed in HEK 293 cells (Gujral and MacBeath, 2010), both triggered $\mathrm{BK}$ channel internalization (Fig. 6) and increased $\beta$-catenin expression (Fig. 7) as recorded by current density measurements. Cotreatment of Wnt3a and EtOH showed no statistical difference in current density from independently treated Wnt3a or EtOHexposed cells. The lack of an additive effect indicates that both are converging on similar targets eliciting the same net effect, BK channel internalization. Furthermore, coincubation of $25 \mathrm{~mm}$ EtOH with the selective $\mathrm{Wnt} / \beta$-catenin inhibitor, IWP-2 $(5 \mu \mathrm{M})$ blocked the characteristic $\mathrm{EtOH}$-induced redistribution in BK channels (Fig. 6A). Both of these experiments support the hypothesis that BK channel surface expression in response to $\mathrm{EtOH}$ is regulated via the $\mathrm{Wnt} / \beta$-catenin pathway.

IWP-2 is an inactivator of Porcn function and therefore an inhibitor of Wnt processing and secretion. By blocking Porcn, it prevents the addition of a palmitoyl group to Wnt proteins, which is essential for their signaling ability and is required for Wnt secretion. The use of IWP-2 thus blocks the $\mathrm{Wnt} / \beta$-catenin pathway by preventing activation of the Wnt receptor. Interestingly, whereas $\beta$-catenin accumulation starts as early as $1 \mathrm{~h}$ after EtOH exposure, IWP-2 does not affect $\beta$-catenin accumulation until after $6 \mathrm{~h}$ exposure and its effects are significant even with $24 \mathrm{~h} \mathrm{EtOH}$ treatment (Fig. 7). Cells exposed to $25 \mathrm{~mm}$ EtOH and 5 $\mu \mathrm{M}$ IWP-2 showed the total amount of $\beta$-catenin increasing after $1 \mathrm{~h}(170.13 \pm$ $27.02 \%)$ and $3 \mathrm{~h}(164.25 \pm 34.72 \%)$. However, IWP-2 significantly blocked $\beta$-catenin during $6 \mathrm{~h} \mathrm{EtOH}$ exposure $(68.83 \pm 7.19 \%)$ and $24 \mathrm{~h}$ by $(46.22 \pm 5.62 \%)$. These findings suggest that Wnt receptor activation does not play a significant role during EtOH exposure until after $6 \mathrm{~h}$ in HEK 293 cells, which coincides with both hSlo $\alpha$ internalization and IWP-2's ability to block this process. Therefore, we speculate that events directly associated with receptor activation are key in mediating internalization only when downstream processes, such as $\beta$-catenin accumulation and possibly GSK inactivation, are in place.

To probe a direct interaction between $\mathrm{Wnt} / \beta$-catenin signaling and the BK channel itself, we used a mutant form of the BK channel, $\alpha$ ZERO isoform hSloAA stably expressed in HEK
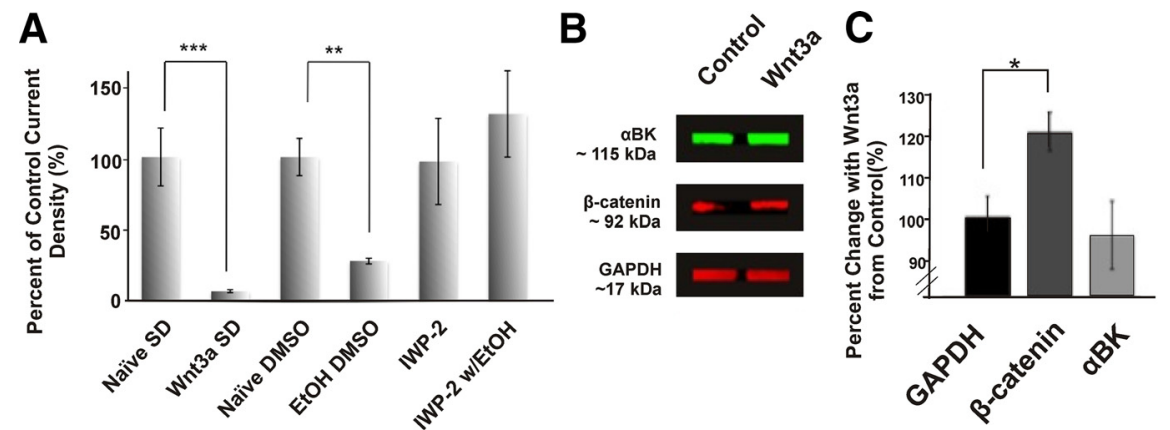

Figure 6. BK expressed in HEK 293 cells shows a decrease in current density when treated with $200 \mathrm{ng} / \mathrm{ml} \mathrm{Wnt-3A}$ (Wnt/ $\beta$ catenin pathway activator), and there is a block in the decrease in current density in the presence of $5 \mu \mathrm{M}$ IWP-2 (Wnt/ $\beta$-catenin inhibitor) when treated for $6 \mathrm{~h}$ with $25 \mathrm{~mm}$ EtOH. $\boldsymbol{A}$, Naive, $200 \mathrm{ng} / \mathrm{ml} \mathrm{Wnt-3A}$, Wnt3a w/EtOH, and $5 \mu \mathrm{M}$ IWP-2 with and without $25 \mathrm{~mm}$ EtOH. Data are mean $\pm \mathrm{SEM} ; n=$ representing the number of individual experiments; $n=5-12$. $\boldsymbol{B}$, Representative Western blot labeled for BK $\alpha, \beta$-catenin, and GAPDH under control and after $6 \mathrm{~h}$ Wnt-3a incubation. $C$, Quantification of all three proteins as percentage change with Wnt3a from control (untreated). Values are normalized to GAPDH expression before determining percentage change. Asterisks represent statistical differences $\left({ }^{*}, p \leq 0.05 ;{ }^{* *}, p \leq 0.01 ;{ }^{* * *}, p \leq 0.001\right) . N=4$ independent experiments, each done in triplicate.
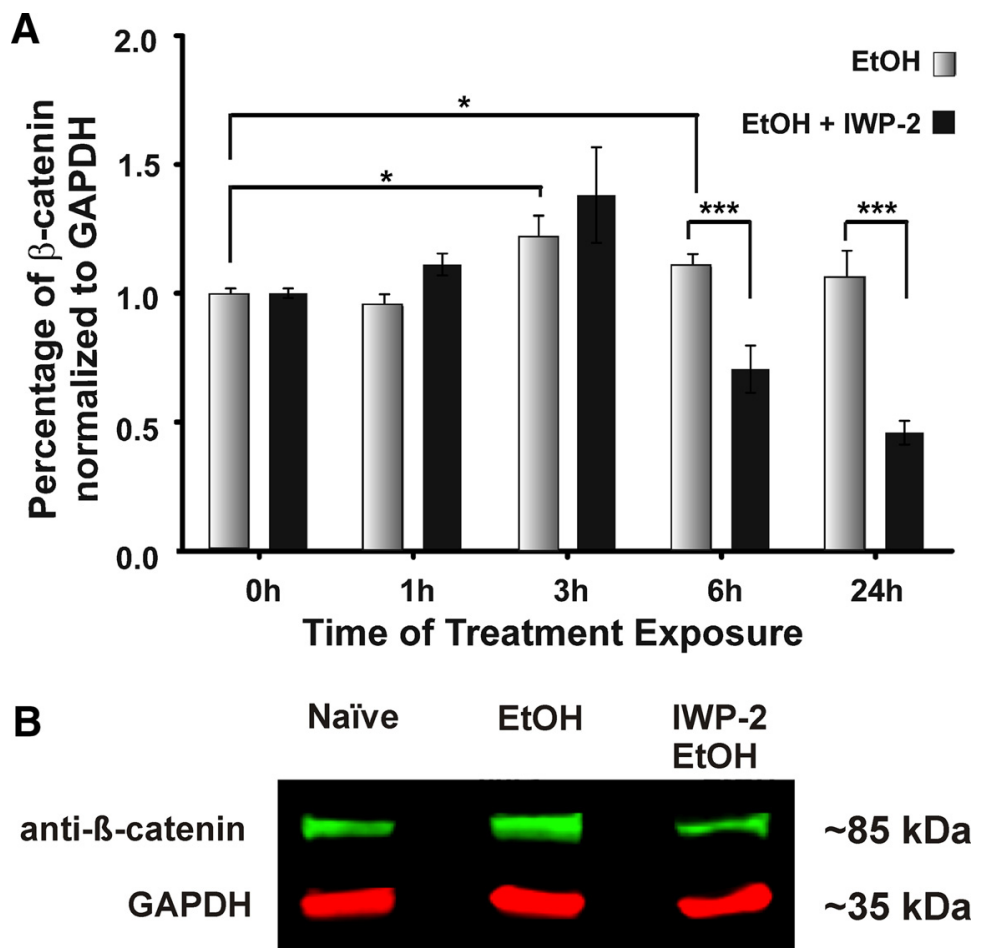

Figure 7. Increases in $\beta$-catenin in response to different time EtOH exposures in HEK293 cells and their response to IWP-2 coincubation. $\boldsymbol{A}$, The analyzed data of the Western blots revealed a nonlinear increase of $\beta$-catenin when exposed to $0,(N=24)$, $1(N=14), 3(N=20), 6(N=18)$, and $24 \mathrm{~h}(N=9)$ with EtOH. The IWP-2 w/EtOH treatment suggests that the increase of $\beta$-catenin at $1(N=3)$ and $3 \mathrm{~h}(N=4)$ is independent to the $W n t / \beta$-catenin signaling pathway. $\boldsymbol{B}$, Western blot imaging shows the increase of $\beta$-catenin in HEK cells when exposed to $6 \mathrm{~h}(N=7)$ of EtOH. EtOH coincubated with IWP-2 decreases $\beta$-catenin expression and blocks the $6 \mathrm{~h}(\mathrm{~N}=4)$ and $24 \mathrm{~h}(\mathrm{~N}=3) \mathrm{EtOH}$-induced increase. GAPDH is used as an internal control. Independent experiments $(N)$ were each done in duplicate. Asterisks represent statistical differences $\left({ }^{*}, p \leq 0.05 ;{ }^{* * *}, p \leq 0.001\right)$.

293 cells (generous gift from D.S. Navaratnam, Yale University). The point mutation focuses on a potential GSK phosphorylation site in the S10 region that contains the consensus GSK phosphorylation motif (SXXXS), rendering the channel constitutively dephosphorylated. Our studies recorded current density measurements in naive and EtOH-treated cells and found no significant current density changes in response to $6 \mathrm{~h} \mathrm{EtOH}$ nor changes in $V_{1 / 2}$ or single-channel conductance (Fig. 8). $\beta$-Catenin signaling still occurred in the pres- 
A

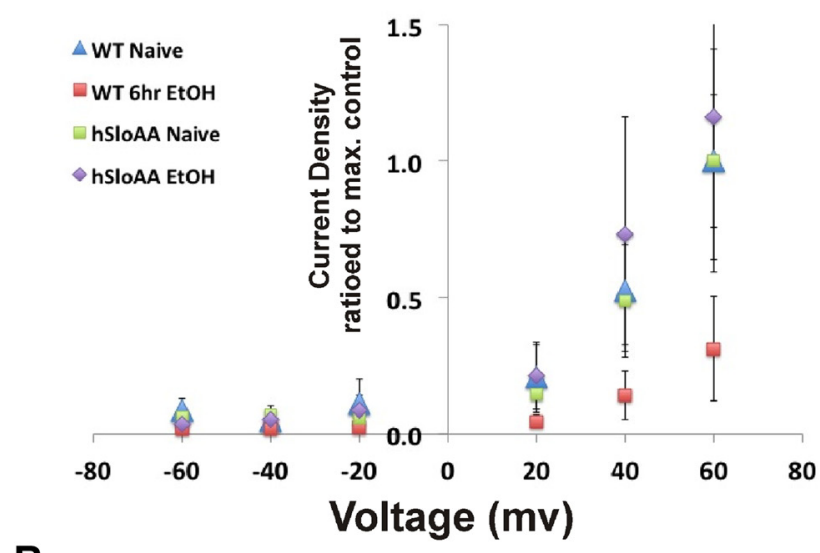

B

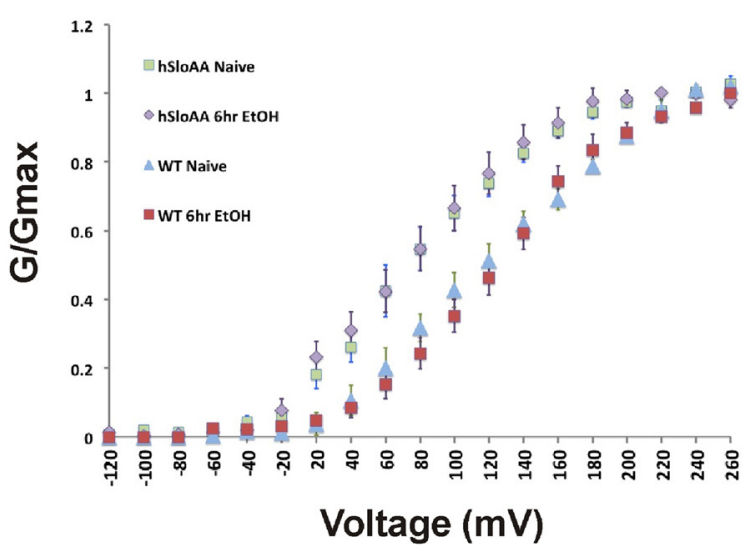

C

\section{$\alpha$ BK Channel Subunit}

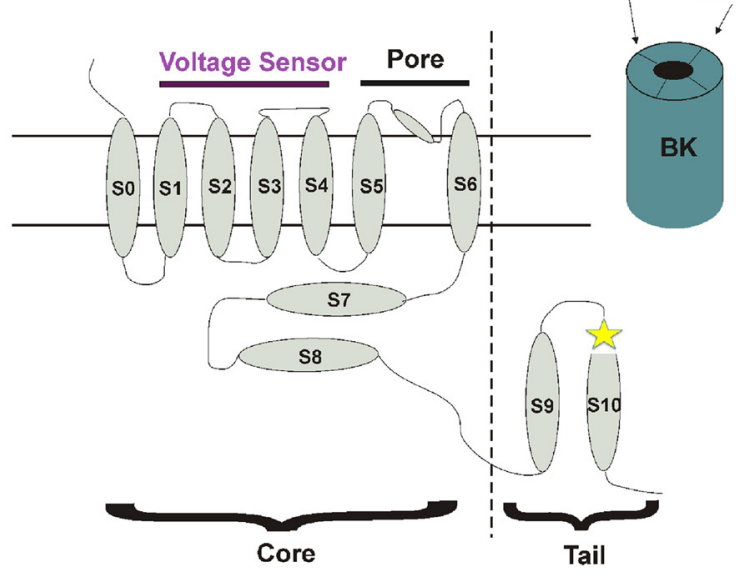

Figure 8. hSloAA stably expressed in HEK293 cells, generously gifted by Dr. Navaratnam (Bian et al., 2011), show no significant change in current density or $G / G m a x$ when exposed for $6 \mathrm{~h}$ with $25 \mathrm{~mm}$ EtOH. $A$, Current density measurements for hSloAA channels with or without 25 $\mathrm{mm}$ EtOH exposure compared with WT naive and $6 \mathrm{~h} \mathrm{EtOH}$ exposed, indicating no significant difference between hSloAA samples and WT naive. $\boldsymbol{B}$, Normalized conductance of hSloAA under naive $(n=8)$ and exposed to $6 \mathrm{~h} 25 \mathrm{~mm} \mathrm{EtOH}(n=6)$ for a range of voltages compared with WT naive and $6 \mathrm{~h}$ EtOH exposed. C, Diagram representing the single point mutation in the S10AA intracellular region of the $\mathrm{hSI}$ OAA mutant (star) that makes a putative GSK phosphorylation site on the BK channel constitutively dephosphorylated (Bian et al., 2011). ence of the hSloAA channel in response to $\mathrm{EtOH}$, yet no change in channel distribution in response to $\mathrm{EtOH}$ took place. When comparing $\mathrm{G} / \mathrm{G}_{\max }$, we find that hSloAA is right shifted to wild-type (WT) unlike previous reports (Bian et al., 2011). However, there is a onefold difference in the pipette solution $\mathrm{Mg}^{2+}$ concentration, which may account for the discrepancy. Studies have shown that $\mathrm{Mg}^{2+}$ has a distinct effect on BK channels conductance-voltage relation showing activation with increasing concentrations (Horrigan and Ma, 2008). These changes are highly dependent on voltage sensor unlike those observed for $\mathrm{Ca}^{2+}$. We therefore, hypothesize that the point mutation within cytoplasmic region of hSloAA may result in a decreased sensitivity to changes in $\mathrm{Mg}^{2+}$ while the WT $G / G_{\max }$ shifts to the right with lower concentrations of $\mathrm{Mg}^{2+}$. Overall our results support the hypothesis that direct interaction between $\beta$-catenin and/or GSK phosphorylation of the hSlo $\alpha$ channel is critical in the $\mathrm{EtOH}$-mediated redistribution of the BK channel characterizing PMT.

\section{Discussion}

The modern view of alcoholism emphasizes that compulsive drinking is rooted in neuronal adaptations within the CNS. Alcohol tolerance is a key element in the development of addiction and is a model for neuronal plasticity. The trafficking of BK channels out of the plasma membrane is part of alcohol molecular tolerance characterized in neuronal systems (Pietrzykowski et al., 2004; Palacio et al., 2015), most recently in the hippocampus, and also in exogenously expressed human BK channels in HEK293 cells. In our current study, we show that $6 \mathrm{~h} \mathrm{EtOH}$ exposure results in internalization of the $\mathrm{BK}$ channel via a protein synthesis-dependent process with BK channels dissociating from lipid raft microdomains. The lipid raft dissociation is not protein synthesis-dependent and may be a necessary primary step in the process of internalization via clathrin-mediated endocytosis. Analysis of de novo synthesized proteins demonstrated $\beta$-catenin synthesis and accumulation in response to $\mathrm{EtOH}$ treatment resulting in levels of $\beta$-catenin that have been shown to activate target genes (Goentoro and Kirschner, 2009) necessary for feedforward triggering of the Wnt canonical signaling pathway (Gosens et al., 2010; Zhang et al., 2015). Secretion of Wnts and subsequent interaction with its Wnt-receptor is required for BK channel internalization after $6 \mathrm{~h}$ EtOH exposure, demonstrated by IWP- 2 inhibition. Activation of the Wnt/ $\beta$-catenin signaling pathway inhibits GSK-3 $\beta$ phosphorylation and subsequent degradation of $\beta$-catenin via sequestration into the activated Wnt receptor complex. We hypothesize that the subsequent lack of GSK phosphorylation of surface BK channels results in its dissociation with $\beta$-catenin and subsequent internalization (Bian et al., 2011) (model shown in Fig. 9). This hypothesis is supported by (1) the lack of change in channel surface expression of the constitutively dephosphorylated mutant form of the BK channel in response to $\mathrm{EtOH}$, and (2) the relatively fast internalization of $\mathrm{BK}$ in response to direct Wnt-receptor activation. Direct interaction between $\mathrm{BK}$ channels and $\beta$-catenin has been well characterized and suggests the presence of more than one site of interaction influencing channel function and surface expression (Lesage et al., 2004; Bian et al., 2011; Zhuang et al., 2011). The sum total of the data supports the hypothesis that the Wnt/ $\beta$ catenin signaling pathway is both necessary and sufficient for BK channel internalization in response to rapid $\mathrm{EtOH}$ exposure. However, effects on gene transcription, with multiple possible targets, may be necessary to sustain the full scope of neuronal adaptations likely mediating long-term alcohol tolerance. 


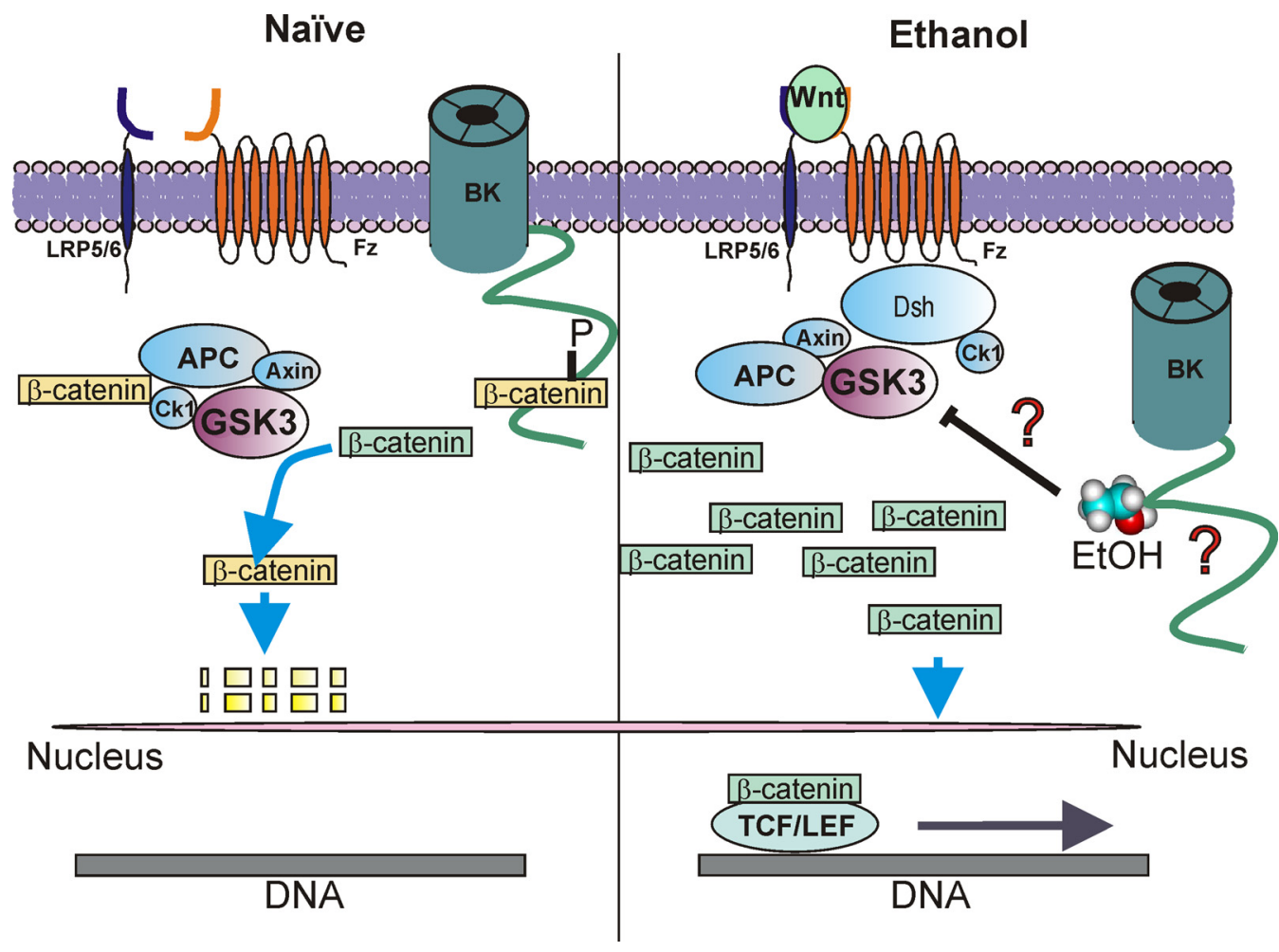

Figure 9. Model for EtOH-induced BK channel internalization via Wnt/ $\beta$-catenin signaling. When the Wnt/ $\beta$-catenin signaling pathway is "off," as under control conditions (naive), the APC/Axin/GSK-3 $\beta$-complex leads to a pattern of $\beta$-catenin phosphoryation (yellow), resulting in its ubiquitination and proteasomal degradation. We hypothesize that GSK-3 $\beta$ is responsible for the phosphorylation of both BK and $\beta$-catenin, resulting in direct association of the channel with $\beta$-catenin. This association supports stable BK surface expression. EtOH is likely inhibiting GSK-3 $\beta$ phosphorylation and potentially directly associating with the BK channel. The inactivation of GSK3 is itself an important step during Wnt/ $\beta$-catenin pathway. Activation of the pathway starts with Wnt associating with its receptor resulting in the GSK-3 $\beta$-complex being sequestered by the protein Dishevelled (Dsh) into a receptor complex restricting $\beta$-catenin phophorylation (green) and presumably BK phosphorylation. This has two important consequences. First, $\beta$-catenin is protected from ubiquitination/degradation. This is followed by $\beta$-catenin accumulation and translocation to the nucleus, where it binds to LEF/TCF transcription factors supporting the transcription of Wnt target genes. Second, the association between $\beta$-catenin and BK is severed, resulting in internalization of the BK channel.

Alcohol tolerance represents a form of neuronal plasticity (Bitrán and Kalant, 1993; Kalant, 1998) involving specific patterns of gene expression and protein profiles (Hoffman et al., 2003; Hoffman and Tabakoff, 2005). Like other forms of plasticity, de novo protein synthesis has been shown to be necessary for both rapid and chronic tolerance to EtOH-induced motor impairment (Bitrán and Kalant, 1993; Kalant, 1993). Here, we show a novel role for Wnt signaling in persistent components of alcohol tolerance, which mechanistically parallel forms of learning and memory, such as LTP. Krug et al. (1984) first demonstrated the role of protein synthesis for the maintenance of LTP beyond $3 \mathrm{~h}$ in the hippocampus where Wnt signaling has been shown to function at synapses, playing a critical role in regulating plasticity (Chen et al., 2006). Slice recordings from CA1 pyramidal neurons further show $\mathrm{K}^{+}$-selective channels are actively internalized from dendrites, thus enhancing intrinsic excitability essential to the development of LTP (Jung and Hoffman, 2009). Interestingly, chronic EtOH consumption in rats results in a decreased stimulation threshold for inducing LTP in CA1 neurons (Fujii et al., 2008), consistent with our results with EtOH-treated hippocampal neurons. In humans, chronic EtOH consumption has been associated with activation of the $\mathrm{Wnt} / \beta$-catenin signaling pathway of cortical brain regions (Al-Housseini et al., 2008; Himes et al., 2008; Mercer et al., 2015). While deregulation of this pathway, as a result of prenatal alcohol exposure, has been suggested as a major factor in the development of fetal alcohol syndrome (Singh et al., 2009; Serrano et al., 2010; Flentke et al., 2011, 2014). However, this is the first time that alcohol molecular tolerance has been linked to regulation of BK channel trafficking via the Wnt/ $\beta$-catenin signaling pathway, mechanistically and functionally representing a distinct form of persistent neuronal plasticity.

Chronic exposure to alcohol decreases BK channel macroscopic currents (Knott et al., 2002; Pietrzykowski et al., 2004) via BK internalization, presumably increasing neuronal excitability in neurohypophysial terminals as observed in hippocampus neurons (Fujii et al., 2008). In the inferior colliculus, alcohol elicits a persistent decrease in BK channel current density in response to $\mathrm{EtOH}$ exposure lasting up to $24 \mathrm{~h}$ after withdrawal ( $\mathrm{N}^{\prime}$ Gouemo and Morad, 2014). These decreases were associated with changes in intrinsic excitability initially thought to be responsible for the generation of alcohol withdrawal hyperactivity leading to seizures. While the contribution of alcohol-induced Wnt $/ \beta$-catenin signaling to decreased current density has not been established in this and other systems, research shows clear differences in $\beta$-catenin localization and activation throughout various brain regions (Wisniewska, 2013). This suggests that there may be some circuit specificity to alcohol-induced Wnt signaling regulation of BK channel expression.

Within the nucleus accumbens, the main circuit involved in alcohol-dependent behavior, chronic intermittent alcohol exposure results in decreased intrinsic excitability suggesting greater $\mathrm{K}^{+}$channel activity (Marty and Spigelman, 2012). As previously noted (Marty and Spigelman, 2012), this is consistent with the development of PMT involving the upregulated expression of STREX, the alcohol-insensitive isoform of BK (VelázquezMarrero et al., 2011) with increased calcium sensitivity, activa- 
tion rate, and mean open time. We hypothesize that rapid exposure to alcohol $(6 \mathrm{~h})$ within the nucleus accumbens contributes to the process of PMT via specific internalization of the ZERO, alcohol-sensitive isoform. Thus, trafficking of BK represents a key component of alcohol tolerance, as a form of long-term adaptation, with associated circuit-specific and exposure-dependent changes in intrinsic excitability.

The development of alcohol tolerance has been shown to also involve changes in lipid microenvironment (Roth and Seeman, 1972; Chin and Goldstein, 1977; Crowley et al., 2003; Dolganiuc et al., 2006; Pietrzykowski et al., 2008; Yuan et al., 2008). For the first time, we show that EtOH exposure $(6 \mathrm{~h})$ shifts a portion of BK channels from caveolin-enriched lipid raft fractions to nonlipid raft fractions, in a protein synthesis-independent manner. It is tempting to speculate that a part of the BK channel population exists within cholesterol-rich lipid rafts and following acute exposure this association is disrupted, as has been previously shown for BK channel clustering (Pietrzykowski et al., 2004; VelázquezMarrero et al., 2011; Palacio et al., 2015). Interestingly, cholesterol depletion leads to an increase in BK channel whole-cell current (Yuan et al., 2011; Wu et al., 2013), suggesting that dissociation of the BK channel from lipid rafts underlies the characteristic increase in channel activity in response to acute EtOH exposure. Although the specific mechanism for endocytosis of BK channels is not known, dissociation from caveolin-enriched lipid microdomains suggests the possibility of a lipid raft independent clathrin-mediated endocytic pathway (El-Sayed and Harashima, 2013). There are several examples of potassium channels actively internalized via clathrin (Kim et al., 2007; Mason et al., 2008; Xu et al., 2009; Kohl et al., 2011; Ortega et al., 2012; Schwab et al., 2012), including regulated internalization of BK channels via WNK4-kinase (Zhuang et al., 2011). Interestingly, clathrin is also required for A-type potassium channel internalization associated with synapse-specific LTP induction in hippocampus (Jung and Hoffman, 2009). Therefore, although dissociation may not be sufficient for BK channel internalization, it may be a necessary first step for internalization and a key component of the acute $\mathrm{BK}$ channel response to $\mathrm{EtOH}$.

The results outlined in this paper describe a unique link between alcohol-induced persistent molecular changes in BK surface expression and $\mathrm{Wnt} / \beta$-catenin signaling, which highlight mechanistic similarities to other forms of neuronal plasticity. The role of Wnt signaling in alcohol tolerance offers uniquely testable clinical approaches in the ongoing challenge to find effective alcohol dependence and prevention treatment strategies.

\section{References}

Al-Housseini AM, Sivanandam TM, Bradbury EL, Tannenberg RK, Dodd PR, $\mathrm{Gu} \mathrm{Q}$ (2008) Upregulation of beta-catenin levels in superior frontal cortex of chronic alcoholics. Alcohol Clin Exp Res 32:1080-1090. CrossRef Medline

Baliga BS, Pronczuk AW, Munro HN (1969) Mechanism of cycloheximide inhibition of protein synthesis in a cell-free system prepared from rat liver. J Biol Chem 244:4480-4489. Medline

Bettinger JC, Davies AG (2014) The role of the BK channel in ethanol response behaviors: evidence from model organism and human studies. Front Physiol 5:346. CrossRef Medline

Bian S, Bai JP, Chapin H, Le Moellic C, Dong H, Caplan M, Sigworth FJ, Navaratnam DS (2011) Interactions between beta-catenin and the HSlo potassium channel regulates HSlo surface expression. PLoS One 6:e28264. CrossRef Medline

Bitrán M, Kalant H (1993) Effect of anisomycin on the development of rapid tolerance to ethanol-induced motor impairment. Pharmacol Biochem Behav 45:225-228. CrossRef Medline

Bliss TV, Collingridge GL (1993) A synaptic model of memory: long-term potentiation in the hippocampus. Nature 361:31-39. CrossRef Medline
Brodie MS, Scholz A, Weiger TM, Dopico AM (2007) Ethanol interactions with calcium-dependent potassium channels. Alcohol Clin Exp Res 31: 1625-1632. CrossRef Medline

Casadio A, Martin KC, Giustetto M, Zhu H, Chen M, Bartsch D, Bailey CH, Kandel ER (1999) A transient, neuron-wide form of CREB-mediated long-term facilitation can be stabilized at specific synapses by local protein synthesis. Cell 99:221-237. CrossRef Medline

Chen J, Park CS, Tang SJ (2006) Activity-dependent synaptic Wnt release regulates hippocampal long term potentiation. J Biol Chem 281:11910 11916. CrossRef Medline

Chin JH, Goldstein DB (1977) Drug tolerance in biomembranes: a spin label study of the effects of ethanol. Science 196:684-685. CrossRef Medline

Contet C, Goulding SP, Kuljis DA, Barth AL (2016) BK channels in the central nervous system. Int Rev Neurobiol 128:281-342. CrossRef Medline

Cowmeadow RB, Krishnan HR, Ghezzi A, Al'Hasan YM, Wang YZ, Atkinson NS (2006) Ethanol tolerance caused by slowpoke induction in Drosophila. Alcohol Clin Exp Res 30:745-753. CrossRef Medline

Craig R, Beavis RC (2004) TANDEM: matching proteins with tandem mass spectra. Bioinformatics 20:1466-1467. CrossRef Medline

Crowley JJ, Treistman SN, Dopico AM (2003) Cholesterol antagonizes ethanol potentiation of human brain BKCa channels reconstituted into phospholipid bilayers. Mol Pharmacol 64:365-372. CrossRef Medline

Dalskov SM, Immerdal L, Niels-Christiansen LL, Hansen GH, Schousboe A, Danielsen EM (2005) Lipid raft localization of GABA A receptor and $\mathrm{Na}^{+}, \mathrm{K}^{+}$-ATPase in discrete microdomain clusters in rat cerebellar granule cells. Neurochem Int 46:489-499. CrossRef Medline

De Ferrari GV, Moon RT (2006) The ups and downs of Wnt signaling in prevalent neurological disorders. Oncogene 25:7545-7553. CrossRef Medline

Dias C, Feng J, Sun H, Shao NY, Mazei-Robison MS, Damez-Werno D, Scobie K, Bagot R, LaBonté B, Ribeiro E, Liu X, Kennedy P, Vialou V, Ferguson D, Peña C, Calipari ES, Koo JW, Mouzon E, Ghose S, Tamminga $\mathrm{C}$, et al. (2014) $\beta$-Catenin mediates stress resilience through $\mathrm{Di}$ cer1/microRNA regulation. Nature 516:51-55. CrossRef Medline

Dolganiuc A, Bakis G, Kodys K, Mandrekar P, Szabò G (2006) Acute ethanol treatment modulates Toll-like receptor-4 association with lipid rafts. Alcohol Clin Exp Res 30:76-85. CrossRef Medline

Dopico AM, Bukiya AN (2014) Lipid regulation of BK channel function. Front Physiol 5:312. CrossRef Medline

Dopico AM, Bukiya AN, Singh AK (2012) Large conductance, calcium- and voltage-gated potassium (BK) channels: regulation by cholesterol. Pharmacol Ther 135:133-150. CrossRef Medline

Dopico AM, Bukiya AN, Martin GE (2014) Ethanol modulation of mammalian BK channels in excitable tissues: molecular targets and their possible contribution to alcohol-induced altered behavior. Front Physiol 5:466. Medline

El-Sayed A, Harashima H (2013) Endocytosis of gene delivery vectors: from clathrin-dependent to lipid raft-mediated endocytosis. Mol Ther 21: 1118-1130. CrossRef Medline

Feinberg-Zadek PL, Martin G, Treistman SN (2008) BK channel subunit composition modulates molecular tolerance to ethanol. Alcohol Clin Exp Res 32:1207-1216. CrossRef Medline

Flentke GR, Garic A, Amberger E, Hernandez M, Smith SM (2011) Calcium-mediated repression of beta-catenin and its transcriptional signaling mediates neural crest cell death in an avian model of fetal alcohol syndrome. Birth Defects Res A Clin Mol Teratol 91:591-602. CrossRef Medline

Flentke GR, Garic A, Hernandez M, Smith SM (2014) CaMKII represses transcriptionally active beta-catenin to mediate acute ethanol neurodegeneration and can phosphorylate beta-catenin. J Neurochem 128:523535. CrossRef Medline

Frey U, Morris RG (1997) Synaptic tagging and long-term potentiation. Nature 385:533-536. CrossRef Medline

Fujii S, Yamazaki Y, Sugihara T, Wakabayashi I (2008) Acute and chronic ethanol exposure differentially affect induction of hippocampal LTP. Brain Res 1211:13-21. CrossRef Medline

Ghezzi A, Pohl JB, Wang Y, Atkinson NS (2010) BK channels play a counter-adaptive role in drug tolerance and dependence. Proc Natl Acad Sci U S A 107:16360-16365. CrossRef Medline

Goentoro L, Kirschner MW (2009) Evidence that fold-change, and not ab- 
solute level, of beta-catenin dictates Wnt signaling. Mol Cell 36:872-884. CrossRef Medline

Gosens R, Baarsma HA, Heijink IH, Oenema TA, Halayko AJ, Meurs H, Schmidt M (2010) De novo synthesis of $\beta$-catenin via H-Ras and MEK regulates airway smooth muscle growth. FASEB J 24:757-768. CrossRef Medline

Gujral TS, MacBeath G (2010) A system-wide investigation of the dynamics of Wnt signaling reveals novel phases of transcriptional regulation. PLoS One 5:e10024. CrossRef Medline

Hamill OP, Marty A, Neher E, Sakmann B, Sigworth FJ (1981) Improved patch-clamp techniques for high-resolution current recording from cells and cell-free membrane patches. Pflugers Arch 391:85-100.

Hannoush RN (2008) Kinetics of Wnt-driven beta-catenin stabilization revealed by quantitative and temporal imaging. PLoS One 3:e3498. CrossRef Medline

Hawkins RD, Abrams TW, Carew TJ, Kandel ER (1983) A cellular mechanism of classical conditioning in Aplysia: activity-dependent amplification of presynaptic facilitation. Science 219:400-405. CrossRef Medline

Himes R, Wezeman FH, Callaci JJ (2008) Identification of novel bonespecific molecular targets of binge alcohol and ibandronate by transcriptome analysis. Alcohol Clin Exp Res 32:1167-1180. CrossRef Medline

Hoffman P, Tabakoff B (2005) Gene expression in animals with different acute responses to ethanol. Addict Biol 10:63-69. CrossRef Medline

Hoffman PL, Miles M, Edenberg HJ, Sommer W, Tabakoff B, Wehner JM, Lewohl J (2003) Gene expression in brain: a window on ethanol dependence, neuroadaptation, and preference. Alcohol Clin Exp Res 27: 155-168. CrossRef Medline

Horrigan FT, Ma Z (2008) $\mathrm{Mg}^{2+}$ enhances voltage sensor/gate coupling in BK channels. J Gen Physiol 131:13-32. CrossRef Medline

Johnson RC, Lemire SW, Woolfitt AR, Ospina M, Preston KP, Olson CT, Barr JR (2005) Quantification of ricinine in rat and human urine: a biomarker for ricin exposure. J Anal Toxicol 29:149-155. CrossRef Medline

Jung SC, Hoffman DA (2009) Biphasic somatic A-type K channel downregulation mediates intrinsic plasticity in hippocampal CA1 pyramidal neurons. PLoS One 4:e6549. CrossRef Medline

Kalant H (1993) Problems in the search for mechanisms of tolerance. Alcohol Alcohol Suppl 2:1-8. Medline

Kalant H (1998) Research on tolerance: what can we learn from history? Alcohol Clin Exp Res 22:67-76. CrossRef Medline

Kauer JA, Malenka RC (2007) Synaptic plasticity and addiction. Nat Rev Neurosci 8:844-858. CrossRef Medline

Kelleher RJ 3rd, Govindarajan A, Jung HY, Kang H, Tonegawa S (2004) Translational control by MAPK signaling in long-term synaptic plasticity and memory. Cell 116:467-479. CrossRef Medline

Kim J, Jung SC, Clemens AM, Petralia RS, Hoffman DA (2007) Regulation of dendritic excitability by activity-dependent trafficking of the A-type $\mathrm{K}^{+}$channel subunit Kv4.2 in hippocampal neurons. Neuron 54:933-947. CrossRef Medline

Knott TK, Dopico AM, Dayanithi G, Lemos J, Treistman SN (2002) Integrated channel plasticity contributes to alcohol tolerance in neurohypophysial terminals. Mol Pharmacol 62:135-142.

Kohl T, Lörinczi E, Pardo LA, Stühmer W (2011) Rapid internalization of the oncogenic $\mathrm{K}^{+}$channel $\mathrm{K}(\mathrm{V}) 10.1$. PLoS One 6:e26329. CrossRef Medline

Krug M, Lossner B, Lössner B, Ott T (1984) Anisomycin blocks the late phase of long-term potentiation in the dentate gyrus of freely moving rats. Brain Res Bull 13:39-42. CrossRef Medline

Lee YS, Silva AJ (2009) The molecular and cellular biology of enhanced cognition. Nat Rev Neurosci 10:126-140. CrossRef Medline

Lesage F, Hibino H, Hudspeth AJ (2004) Association of beta-catenin with the alpha-subunit of neuronal large-conductance $\mathrm{Ca}^{2+}$-activated $\mathrm{K}^{+}$ channels. Proc Natl Acad Sci U S A 101:671-675. CrossRef Medline

Levitan IB (2008) miXED messages in ion channel modulation. Neuron 59:188-189. CrossRef Medline

Lin YC, Boone M, Meuris L, Lemmens I, Van Roy N, Soete A, Reumers J, Moisse M, Plaisance S, Drmanac R, Chen J, Speleman F, Lambrechts D, Van de Peer Y, Tavernier J, Callewaert N (2014) Genome dynamics of the human embryonic kidney 293 lineage in response to cell biology manipulations. Nat Commun 5:4767. CrossRef Medline

Mameli M, Halbout B, Creton C, Engblom D, Parkitna JR, Spanagel R, Lüscher C (2009) Cocaine-evoked synaptic plasticity: persistence in the
VTA triggers adaptations in the NAc. Nat Neurosci 12:1036-1041. CrossRef Medline

Martens JR, Navarro-Polanco R, Coppock EA, Nishiyama A, Parshley L, Grobaski TD, Tamkun MM (2000) Differential targeting of Shaker-like potassium channels to lipid rafts. J Biol Chem 275:7443-7446. CrossRef Medline

Martens JR, O'Connell K, Tamkun M (2004) Targeting of ion channels to membrane microdomains: localization of KV channels to lipid rafts. Trends Pharmacol Sci 25:16-21. CrossRef Medline

Martin GE, Hendrickson LM, Penta KL, Friesen RM, Pietrzykowski AZ, Tapper AR, Treistman SN (2008) Identification of a BK channel auxiliary protein controlling molecular and behavioral tolerance to alcohol. Proc Natl Acad Sci U S A 105:17543-17548. CrossRef Medline

Marty VN, Spigelman I (2012) Effects of alcohol on the membrane excitability and synaptic transmission of medium spiny neurons in the nucleus accumbens. Alcohol 46:317-327. CrossRef Medline

Mason AK, Jacobs BE, Welling PA (2008) AP-2-dependent internalization of potassium channel Kir2.3 is driven by a novel di-hydrophobic signal. J Biol Chem 283:5973-5984. CrossRef Medline

McGaugh JL (2000) Memory: a century of consolidation. Science 287: 248-251. CrossRef Medline

Mercer KE, Hennings L, Ronis MJ (2015) Alcohol consumption, Wnt/ beta-catenin signaling, and hepatocarcinogenesis. Adv Exp Med Biol 815:185-195. CrossRef Medline

Mulholland PJ, Hopf FW, Bukiya AN, Martin GE, Liu J, Dopico AM, Bonci A, Treistman SN, Chandler LJ (2009) Sizing up ethanol-induced plasticity: the role of small and large conductance calcium-activated potassium channels. Alcohol Clin Exp Res 33:1125-1135. CrossRef Medline

N'Gouemo P, Morad M (2014) Alcohol withdrawal is associated with a downregulation of large-conductance $\mathrm{Ca}(2)(+)$-activated $\mathrm{K}(+)$ channels in rat inferior colliculus neurons. Psychopharmacology (Berl) 231: 2009-2018. CrossRef Medline

Oliva CA, Vargas JY, Inestrosa NC (2013) Wnt signaling: role in LTP, neural networks and memory. Ageing Res Rev 12:786-800. CrossRef Medline

Ortega B, Mason AK, Welling PA (2012) A tandem di-hydrophobic motif mediates clathrin-dependent endocytosis via direct binding to the AP-2 alphasigma2 subunits. J Biol Chem 287:26867-26875. CrossRef Medline

Palacio S, Velázquez-Marrero C, Marrero HG, Seale GE, Yudowski GA, Treistman SN (2015) Time-dependent effects of ethanol on BK channel expression and trafficking in hippocampal neurons. Alcohol Clin Exp Res 39:1619-1631. CrossRef Medline

Pascoli V, Terrier J, Espallergues J, Valjent E, O'Connor EC, Lüscher C (2014) Contrasting forms of cocaine-evoked plasticity control components of relapse. Nature 509:459-464. CrossRef Medline

Perkins DN, Pappin DJ, Creasy DM, Cottrell JS (1999) Probability-based protein identification by searching sequence databases using mass spectrometry data. Electrophoresis 20:3551-3567. CrossRef Medline

Pietrzykowski AZ, Martin GE, Puig SI, Knott TK, Lemos JR, Treistman SN (2004) Alcohol tolerance in large-conductance, calcium-activated potassium channels of CNS terminals is intrinsic and includes two components: decreased ethanol potentiation and decreased channel density. J Neurosci 24:8322-8332. CrossRef Medline

Pietrzykowski AZ, Friesen RM, Martin GE, Puig SI, Nowak CL, Wynne PM, Siegelmann HT, Treistman SN (2008) Posttranscriptional regulation of BK channel splice variant stability by miR- 9 underlies neuroadaptation to alcohol. Neuron 59:274-287. CrossRef Medline

Pietrzykowski AZ, Ortiz-Miranda S, Knott TK, Custer E, Puig S, Lemos JR, Treistman SN (2013) Molecular tolerance of voltage-gated calcium channels is evident after short exposures to alcohol in vasopressinreleasing nerve terminals. Alcohol Clin Exp Res 37:933-940. CrossRef Medline

Pike LJ (2009) The challenge of lipid rafts. J Lipid Res 50 [Suppl]:S323-S328.

Pristerà A, Baker MD, Okuse K (2012) Association between tetrodotoxin resistant channels and lipid rafts regulates sensory neuron excitability. PLoS One 7:e40079. CrossRef Medline

Remaud J, Ceccom J, Carponcy J, Dugué L, Menchon G, Pech S, Halley H, Francés B, Dahan L (2014) Anisomycin injection in area CA3 of the hippocampus impairs both short-term and long-term memories of contextual fear. Learn Mem 21:311-315. CrossRef Medline

Roth S, Seeman P (1972) The membrane concentrations of neutral and positive anesthetics (alcohols, chlorpromazine, morphine) fit the Meyer- 
Overton rule of anesthesia: negative narcotics do not. Biochim Biophys Acta 255:207-219. CrossRef Medline

Schneider-Poetsch T, Ju J, Eyler DE, Dang Y, Bhat S, Merrick WC, Green R, Shen B, Liu JO (2010) Inhibition of eukaryotic translation elongation by cycloheximide and lactimidomycin. Nat Chem Biol 6:209-217. CrossRef Medline

Schuckit MA (1994) Low level of response to alcohol as a predictor of future alcoholism. Am J Psychiatry 151:184-189. CrossRef Medline

Schwab A, Nechyporuk-Zloy V, Gassner B, Schulz C, Kessler W, Mally S, Römer M, Stock C (2012) Dynamic redistribution of calcium sensitive potassium channels $(\mathrm{hK}(\mathrm{Ca}) 3.1)$ in migrating cells. J Cell Physiol 227: 686-696. CrossRef Medline

Serrano M, Han M, (2010) Fetal alcohol syndrome: cardiac birth defects in mice and prevention with folate. Am J Obstet Gynecol 203:e7-e75. CrossRef Medline

Shaw G, Morse S, Ararat M, Graham FL (2002) Preferential transformation of human neuronal cells by human adenoviruses and the origin of HEK 293 cells. FASEB J 16:869-871. CrossRef Medline

Siegelbaum SA, Bolshakov VY (1996) Response: long-term potentiation in the CA1 hippocampus. Science 271:1605-1606. CrossRef Medline

Siegelbaum SA, Kandel ER (1991) Learning-related synaptic plasticity: LTP and LTD. Curr Opin Neurobiol 1:113-120. CrossRef Medline

Simons K, Ikonen E (1997) Functional rafts in cell membranes. Nature 387: 569-572. CrossRef Medline

Singh AK, Gupta S, Jiang Y, Younus M, Ramzan M (2009) In vitro neurogenesis from neural progenitor cells isolated from the hippocampus region of the brain of adult rats exposed to ethanol during early development through their alcohol-drinking mothers. Alcohol Alcohol 44:185-198. CrossRef Medline

Sutton MA, Schuman EM (2006) Dendritic protein synthesis, synaptic plasticity, and memory. Cell 127:49-58. CrossRef Medline

Szabò I, Adams C, Gulbins E (2004) Ion channels and membrane rafts in apoptosis. Pflugers Arch 448:304-312. CrossRef Medline

Tajima N, Itokazu Y, Korpi ER, Somerharju P, Käkelä R (2011) Activity of $\mathrm{BK}(\mathrm{Ca})$ channel is modulated by membrane cholesterol content and association with $\mathrm{Na}^{+} / \mathrm{K}^{+}$-ATPase in human melanoma IGR39 cells. J Biol Chem 286:5624-5638. CrossRef Medline

Treistman SN, Wilson A (1991) Effects of chronic ethanol on currents carried through calcium channels in Aplysia. Alcohol Clin Exp Res 15: 489-493. CrossRef Medline
Treistman SN, Martin GE (2009) BK channels: mediators and models for alcohol tolerance. Trends Neurosci 32:629-637. CrossRef Medline

Tsvetkov AS, Mitra S, Finkbeiner S (2009) Protein turnover differences between neurons and other cells. Autophagy 5:1037-1038. CrossRef Medline

Velázquez-Marrero C, Wynne P, Bernardo A, Palacio S, Martin G, Treistman SN (2011) The relationship between duration of initial alcohol exposure and persistence of molecular tolerance is markedly nonlinear. J Neurosci 31:2436-2446. CrossRef Medline

Velázquez-Marrero C, Seale GE, Treistman SN, Martin GE (2014) Large conductance voltage- and $\mathrm{Ca}^{2+}$-gated potassium (BK) channel $\beta 4$ subunit influences sensitivity and tolerance to alcohol by altering its response to kinases. J Biol Chem 289:29261-29272. CrossRef Medline

Wang B, Jaffe DB, Brenner R (2014) Current understanding of iberiotoxinresistant BK channels in the nervous system. Front Physiol 5:382. CrossRef Medline

Wisniewska MB (2013) Physiological role of beta-catenin/TCF signaling in neurons of the adult brain. Neurochem Res 38:1144-1155. CrossRef Medline

Wu W, Wang Y, Deng XL, Sun HY, Li GR (2013) Cholesterol downregulates BK channels stably expressed in HEK 293 cells. PLoS One 8:e79952. CrossRef Medline

Wu X, Hernandez-Enriquez B, Banas M, Xu R, Sesti F (2013) Molecular mechanisms underlying the apoptotic effect of $\mathrm{KCNB} 1 \mathrm{~K}^{+}$channel oxidation. J Biol Chem 288:4128-4134. CrossRef Medline

Xu X, Kanda VA, Choi E, Panaghie G, Roepke TK, Gaeta SA, Christini DJ, Lerner DJ, Abbott GW (2009) MinK-dependent internalization of the IKs potassium channel. Cardiovasc Res 82:430-438. CrossRef Medline

Yuan C, O'Connell RJ, Wilson A, Pietrzykowski AZ, Treistman SN (2008) Acute alcohol tolerance is intrinsic to the BKCa protein, but is modulated by the lipid environment. J Biol Chem 283:5090-5098. CrossRef Medline

Yuan C, Chen M, Covey DF, Johnston LJ, Treistman SN (2011) Cholesterol tuning of $\mathrm{BK}$ ethanol response is enantioselective, and is a function of accompanying lipids. PLoS One 6:e27572. CrossRef Medline

Zhang MZ, Ferrigno O, Wang Z, Ohnishi M, Prunier C, Levy L, Razzaque M, Horne WC, Romero D, Tzivion G, Colland F, Baron R, Atfi A (2015) TGIF governs a feedforward network that empowers Wnt signaling to drive mammary tumorigenesis. Cancer Cell 27:547-560. CrossRef Medline

Zhuang J, Zhang X, Wang D, Li J, Zhou B, Shi Z, Gu D, Denson DD, Eaton DC, Cai H (2011) WNK4 kinase inhibits Maxi K channel activity by a kinase-dependent mechanism. Am J Physiol Renal Physiol 301:F410 F419. CrossRef Medline 